University of Arkansas at Little Rock William H. Bowen School of Law Bowen Law Repository: Scholarship \& Archives

Faculty Scholarship

2011

\title{
A Primer on the History and Proper Drafting of Qualified Domestic-Relations Orders
}

Terrence Cain

University of Arkansas at Little Rock William H. Bowen School of Law, txcain@ualr.edu

Follow this and additional works at: http://lawrepository.ualr.edu/faculty_scholarship

Part of the Family Law Commons, and the Retirement Security Commons

\section{Recommended Citation}

Terrence Cain, A Primer on the History and Proper Drafting of Qualified Domestic-Relations Orders, 28 T.M. Cooley L. Rev. 417 (2011).

This Article is brought to you for free and open access by Bowen Law Repository: Scholarship \& Archives. It has been accepted for inclusion in Faculty Scholarship by an authorized administrator of Bowen Law Repository: Scholarship \& Archives. For more information, please contact mmserfass@ualr.edu. 


\title{
A PRIMER ON THE HISTORY AND PROPER DRAFTING OF QUALIFIED DOMESTIC-RELATIONS ORDERS
}

\author{
TERRENCE CAIN ${ }^{*}$
}

\begin{abstract}
The divorce rate in the United States is slightly more than one-half of the marriage rate. Divorce is a fact of life in this country and will likely be so for the foreseeable future. On August 23, 1984, the divorce lawyer's job became more complicated when Congress created the Qualified Domestic Relations Order (QDRO) as part of significant amendments to the Employee Retirement Income Security Act of 1974 (ERISA). QDROs are necessary because prior to the 1984 amendments to ERISA, many divorced persons discovered that they could be deprived of their marital- or community-property interest in their former spouses' retirement plans. For most divorcing couples, the two largest assets of the marriage are the marital home and retirement accounts. Over ninety-nine million persons participate in private-sector retirement plans, and those plans' assets total more than $\$ 4$ trillion, which exceeds the total value of all residential real estate in the United States. Dividing retirement accounts is not as simple as a court ordering that each party gets one-half of the other party's account. It takes a properly drafted QDRO to make sure that each party gets his or her marital or
\end{abstract}

\footnotetext{
* Assistant Professor of Law, University of Arkansas at Little Rock William H. Bowen School of Law. I owe a deep debt of gratitude to the following persons at the law school where I am privileged, honored, and happy to work: Jada Aitchison, Adjoa A. Aiyetoro, Theresa M. Beiner, Jessie Wallace Burchfield, Paula Casey, John M.A. DiPippa, Michael Dinnerstein, Felecia Epps, Frances S. Fendler, Michael T. Flannery, Lynn Foster, Charles W. Goldner, Jr., Kenneth S. Gould, Sarah Howard Jenkins-Hobbs, Philip D. Oliver, Ranko Shiraki Oliver, Kelly Browe Olson, Melissa M. Serfass, Joshua M. Silverstein, J. Thomas Sullivan, and Kelly S. Terry. I also want to offer a special thank you to the Honorable Robin Mays, Judge for the Sixth Judicial District of the State of Arkansas (retired), Kristen Green, and Caleb Garcia. Judge Mays was my domestic-relations professor when I was a law student and taught me what a QDRO is and why it is important. Ms. Green and Mr. Garcia are former students and current inspirations who are always there to remind me that when I get disillusioned I should keep my focus on my students. Any errors in this article are solely my own.
} 
community-property share of the other's retirement benefits. Drafting a QDRO can be time consuming, complex, and frustrating, in part because it requires lawyers who primarily practice state law to have a working knowledge of parts of the notoriously lengthy and complex ERISA. A substantial number-perhaps a majority-of QDROs are not prepared properly because they do not reflect the parties' understanding of what they were awarded in the divorce proceeding. In fact, a former administrator for a retirement plan stated that between $15 \%$ and $20 \%$ of the time, lawyers fail to see a QDRO through to completion. This Article will detail the history leading to the creation of QDROs, explain what QDROs are, and offer suggestions on what pitfalls to look for and avoid in drafting them.

\section{TABLE OF CONTENTS}

INTRODUCTION

I. The STATUS OF EMPLOYEE PENSIONS AND RETIREMENT

PLANS BEFORE ERISA

A. The Studebaker Shutdown .............................................426

B. The Long, Wending Path to Pension-Termination Insurance .......................................433

C. The Enactment of ERISA ..............................................436

1. ERISA's Spendthrift Provision .................................439

2. ERISA Preemption .................................................443

II. THE REA, THE SURVIVOR ANNUITY, AND THE BIRTH OF

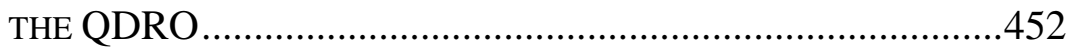

A. The Survivor Annuity .................................................... 452

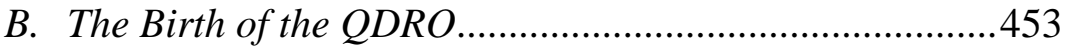

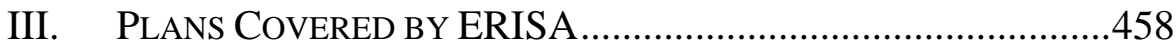

A. Defined-Benefit Plans.....................................................458

B. Defined-Contribution Plans .............................................460

C. Cash-Balance Pension Plans ........................................461

IV. COMMON QDRO ERRORS ..................................................463

A. Lack of an Awareness that QDROs Exist or Are

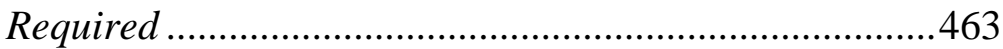

B. Delay in Drafting the QDRO..........................................466

C. Insufficient Understanding of How Annuities Are

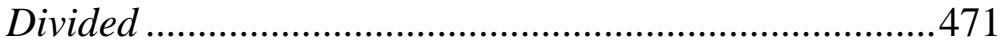

1. Participant is Retired and Receiving Payments.........473

2. Single-Life Annuity on the Life of the Participant....474

3. Qualified Joint-and-Survivor Annuity on the Lives of the Participant and Alternate Payee 
4. Qualified Joint-and-Survivor Annuity on the Lives of the Participant and the New Spouse.

5. Single-Life Annuity on the Life of the Alternate Payee.. 475

D. Uncritically Using the Plan's Model QDRO ..................475

1. No Survivorship Protection ......................................476

2. No Division of the Participant's Tax Basis in Defined-Contribution Plans.....................................477

3. No Provision for Cost-of-Living Adjustments ...........478

4. No Early Retirement Subsidy Allocation...................479

5. Provision for Misdirected Payments .........................480

6. The $10 \%$ Penalty on Early Distributions ...................481

7. Always Using a Shared-Interest Approach with Defined-Benefit Plans .............................................482

a. Separate-Interest Approach .................................482

b. Shared-Interest Approach.......................................484

8. Assigning Vested Benefits Rather than Accrued Benefits .........................................................486

9. Investment Gains and Losses in Defined-Contribution Plans .................................................................486

10. Division of Year-End Contributions ........................487

11. Allocation of Forfeitures ........................................487

12. Proper Handling of Loans in Defined-Contribution Plans ....................................................................490

13. The PBGC and Defined-Benefit Plans ......................490

V. VERIFY THAT THE QDRO Is APPROVED BY THE PlAN

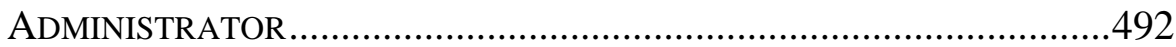

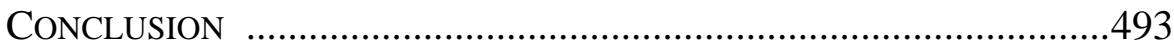

\section{INTRODUCTION}

In 2009, 2,080,000 couples were married in the United States. ${ }^{1}$ That same year, 840,000 couples were divorced. ${ }^{2}$ Many divorces

1. NAT'L Vital Statistics Sys.,Ctrs. FOR DiseAse CONTROL \& Prevention, NAT'L MarRiage And DivorCe RAte Trends (2010), available at http://www.cdc.gov/nchs/nvss/marriage_divorce_tables.htm (last updated Jan. 12, 2012) [hereinafter NAT'L MARRIAGE AND DivORCE RATE TRENDS]. The national rate of marriages per 1,000 persons is 6.8. Id. The rates of marriages per 1,000 persons in the individual states and the District of Columbia (in descending order) are: Nevada (38.3), Hawaii (17.6), Arkansas (10.8), Vermont (9.3), Idaho (8.8), 
require the division of marital assets, which may be done differently depending on whether the couple resides in a community-property state $^{3}$ or a common-law-property state. ${ }^{4}$ In community-property

Tennessee (8.8), Utah (8.5), Alabama (8.2), Alaska (8), New Mexico (7.7), District of Columbia (7.6), Wyoming (7.6), Kentucky (7.4), Montana (7.4), South Carolina (7.4), South Dakota (7.3), New Hampshire (7.3), Florida (7.3), Georgia (7.3), Oklahoma (7.2), Maine (7.1), Texas (7.1), Colorado (6.9), Louisiana (6.9), Iowa (6.9), Virginia (6.8), West Virginia (6.7), Nebraska (6.6), North Carolina (6.6), Missouri (6.5), New York (6.5), North Dakota (6.5), Oregon (6.5), Kansas (6.4), Indiana (6.3), Washington (6), Arizona (5.9), Ohio (5.8), Rhode Island (5.8), California (5.8), Illinois (5.7), Maryland (5.7), Connecticut (5.6), Massachusetts (5.6), Michigan (5.5), Minnesota (5.3), Pennsylvania (5.3), Wisconsin (5.3), Delaware (5.2), New Jersey (5.1), and Mississippi (4.9). NAT'L ViTAL STATiSTiCS Sys., Ctrs. For Disease Control \& Prevention, Marriage Rates by State: 1990, 1995, AND 1999-2010 (2010), available at http://www.cdc.gov/nchs/data/ nvss/marriage_rates_90_95_99-10.pdf (last visited Jan, 12, 2012) [hereinafter MARRIAGE RATES BY STATE].

2. NAT'L MARRIAGE AND DivorCE RATE TRENDS, supra note 1 . The national rate of divorces per 1,000 persons is 3.5. Id. The national divorce count and rate are higher than reported because California, Georgia, Hawaii, Indiana, Louisiana, and Minnesota do not report either divorce counts or rates. Betzaida Tejada-Vera \& Paul D. Sutton, Births, Marriages, Divorces, and Deaths: Provisional Data for 2009, 58 NAT'L Vital Stat. ReP., Aug. 2010, at 1, 2. The rates of Divorces per 1,000 persons in individual states and the District of Columbia (in descending order) are: Nevada (5.9), Arkansas (5.7), Oklahoma (5.2), Idaho (5.2), Wyoming (5.1), West Virginia (5.1), Alaska (4.7), Kentucky (4.5), Alabama (4.4), Florida (4.4), Mississippi (4.3), Colorado (4.3), Maine (4.2) Washington (4.2), Tennessee (4.2), Missouri (3.9), Montana (3.9), New Mexico (4.0), Oregon (4.0), North Carolina (3.8), New Hampshire (3.8), Vermont (3.8), Virginia (3.8), Kansas (3.7), Utah (3.7), Nebraska (3.6), Michigan (3.5), Arizona (3.5), Delaware (3.5), Delaware (3.5), Ohio (3.4), South Dakota (3.4), Texas (3.3), Rhode Island (3.2), North Dakota (3.1), South Carolina (3.1), Wisconsin (3.0), New Jersey (3.0), Connecticut (2.9), New York (2.9), Maryland (2.8), District of Columbia (2.8), Pennsylvania (2.7), Illinois (2.6), Massachusetts (2.5), Iowa (2.4). MARRIAGE RATES By STATE, supra note 1.

3. The eight community-property states are Arizona, California, Idaho, Louisiana, Nevada, New Mexico, Texas, and Washington. Cheyañna L. Jaffke, Death, Taxes, and Now Divorce-The Dyad Expands to a Triad: ERISA's Social Policy Harms Women's Rights, 35 U.S.F. L. ReV. 255, 268 (2001) (citations omitted). Wisconsin has elements of a community-property regime, but it is not a formal community-property state. Id. (citing Howard S. Erlanger \& June M. Weisberger, From Common Law Property to Community Property: Wisconsin's Marital Property Act Four Years Later, 1990 WIS. L. REV. 769, 769 n.2 (1990)).

4. See Jaffke, supra note 3, at 268. The remaining states are common-lawproperty states. Id. 
states, marriage is considered an equal partnership; therefore, any asset acquired during the marriage belongs to both spouses, which entitles each spouse to a one-half ownership interest in the asset. ${ }^{5}$ Any effort expended during the marriage that results in an acquisition of property produces something that belongs to both spouses, regardless of which spouse expended the effort to acquire it. ${ }^{6}$

A majority of the common-law-property states operate similarly to the community-property states in that assets obtained during the marriage are presumed to be marital, which means that each spouse owns one-half of the asset. ${ }^{7}$ This presumption may be rebutted; however, if a court determines that an equal division of marital property would be inequitable in a particular case, then the court may order an unequal division. ${ }^{8}$

In most divorces, the two largest assets that couples own are the marital home and retirement funds. ${ }^{9}$ Division of a marital home is

5. Id.

6. Id.

7. Id. at 269.

8. See Id.

9. David Clayton Carrad, The Complete QDRO Handbook: Dividing ERISA, Military, and Civil Service Pensions and Collecting Child Support from Employee Benefit Plans xxvii (3d ed. A.B.A. 2009); Joshua A. Dean, Wilson v. Wilson: The Effect of QDROs on Appealing Divorce Decrees, 42 AKRON L. REV. 639, 639 n.1 (2009) (citing David L. Baumer \& J.C. Poindexter, Women and Divorce: The Perils of Pension Division, 57 OHIO ST. L.J. 203, 204 (1996)). “[P] ension plans contain the largest block of private capital” in the United States. Id. (citing Hilary Greer Fike, Qualified Pension Trends and Divorce Considerations, 14 AM. J. FAM. L. 234, 234-35 (2000)). In 2000, the Federal Reserve estimated that pension funds held $25 \%$ of the United States' financial assets compared with 2\% in 1950. Hilary Greer Fike, Qualified Pension Trends and Divorce Considerations, 14 AM. J. FAM. L. 234, 234-35 (2000). In 2000, the total value of pension assets exceeded the total value of all residential real estate. Id. "[T]he average American couple has pension assets that are worth as much as the gross value of their (sic) home.” Id. at 235; Mark S. Maddox \& Margaret K. Cassidy, Division of Employee Benefits upon Divorce: An Analysis of the Retirement Equity Act of 1984 and a Framework for Distribution of Benefits, 58 OHIO ST. B. AsS'N REP. 436, 436 (1985) (stating that, in many divorces, the pension rights or employee benefits of one or both spouses are the most significant marital assets owned by the couple and are subject to division in divorce proceedings); Jessica Straub, Note, Erb v. Erb: A Step Toward Clarification in Public Pension Division, 33 U. TOL. L. REV. 915, 916 (2002) (stating that pension plans are crucial in divorces because they, along with the marital home, are often the largest marital asset); Dylan A. Wilde, Article, Obtaining an Equitable Distribution of Retirement Plans in a Divorce Proceeding, 49 S.D. L. REV. 141, 141 (2003) (stating that a 1998 United States Department of Labor study indicated that over 
governed by state domestic-relations law and is not a factually or legally complex undertaking. A court could, for example, grant ownership of the home to one spouse on the condition that he or she "buy out" the other spouse's one-half interest. Conversely, a court could order the marital home to be sold with the parties equally dividing the proceeds. Retirement plans, however, are not so neatly or easily divided.

The division of a retirement plan as an incident of divorce must comply not only with state domestic-relations law, but also with federal law, namely the Employee Retirement Income Security Act of 1974 (ERISA) ${ }^{10}$ and the Retirement Equity Act of 1984 (REA). ${ }^{11}$ Under ERISA $^{12}$ and the REA, a person's pension benefits can only be assigned to another person if the state-court domestic-relations order-an order recognizing the right of a spouse, former spouse, child, or other dependent to receive a part or all of an individual's

ninety-nine million persons participated in private retirement plans, and those plans' assets total more than \$4 trillion); U.S. DEPT. OF LABOR, QDROs: The Division of Retirement Benefits Through Qualified Domestic Relations Orders, DOL.GOV, http://www.dol.gov/ebsa/publications/qdros.html (last visited Jan. 12, 2012). More than forty-six million private-sector workers have employer-provided retirement plans, and for many of these workers, these plans represent one of their most significant assets. Id.

10. Employee Retirement Income Security Act of 1974, Pub. L. No. 93-406, 88 Stat. 829 (codified as amended at 26 U.S.C. $\S \S 219,408,410-415,4971,4973-$ 4975, 6047, 6057-6059, 6690, 6692, 6693, 7476 (2006); 29 U.S.C. §§ 1001-1003, 1021-1031, 1051-1056, 1058-1061, 1081-1085, 1101-1114, 1131-1151, 11611169, 1181-1183, 1185, 1185a-1185d, 1191, 1191a-1191c, 1201-1204, 1221, 1222, 1231, 1232, 1241, 1242, 1301-1310, 1321, 1322, 1322a, 1322b, 1341, 1341a, 1342-1348, 1350, 1361-1371, 1381-1405, 1411-1415, 1421-1426, 1431, 1441, 1451-1453, 1461 (2006)). This law spans two titles and 192 sections of the United States Code (nineteen sections in Title 26, the Internal Revenue Code, and 173 sections in Title 29, Labor). Id. President Gerald R. Ford signed ERISA into law on Labor Day, September 2, 1974. 10 WEEKLY COMP. PRES. DoC. 1084 (Sept. 9, 1974).

11. Retirement Equity Act of 1984, Pub. L. No. 98-397, 98 Stat. 1426 (codified

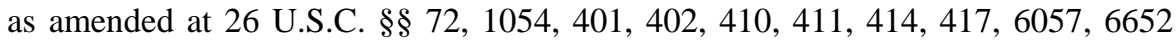
(2006); 29 U.S.C. $\S \S ~ 1001,1025,1052-56,1144$ (2006)). Id. President Ronald Reagan signed the REA into law on August 23, 1984. 20 WEEKLY COMP. PRES. DoC. 1161 (Sept. 3, 1984).

12. Reading this article is going to require putting up with a lot of acronyms. Trs. of the Dirs. Guild of Am.-Producer Pension Benefits Plans v. Tise, 234 F.3d 415, 419 (9th Cir. 2000) (stating that an analysis of ERISA's QDRO provision is a task requiring tolerance for acronyms). 
pension benefits—constitutes a Qualified Domestic Relations Order (QDRO). ${ }^{13}$

Two facts make QDROs necessary in virtually every divorce proceeding. First, there are over 800,000 ERISA-qualified retirement plans in the United States, and those plans contain over \$4 trillion in assets for more than ninety million workers. ${ }^{14}$ Second, the current divorce rate is more than one-half of the current marriage rate. ${ }^{15}$ Simply put, those who practice domestic-relations law need to know how to draft and construe a QDRO. This requires more than uncritically filling in the blanks of a QDRO obtained from a form book or an individual's retirement-plan administrator. Failure to properly handle QDRO issues is professional misconduct that can result in malpractice liability. ${ }^{16}$ In the last ten years, more and more attorneys have been exposed to malpractice liability due to their failure to handle QDROs appropriately. ${ }^{17}$ David Clayton Carrad, a preeminent QDRO authority in the United States, has posited the following four reasons for this trend. ${ }^{18}$

First, an understanding of QDROs requires some understanding of certain parts of ERISA, a notoriously lengthy, complex, and detailed set of statutes that span two titles and 192 sections of the United States Code. ${ }^{19}$ Although a person does not need to be conversant with the entirety of ERISA to properly handle a QDRO, those parts that a person does need to understand can be difficult to

13. 26 U.S.C. § 414(p)(1) (2006); 29 U.S.C. § 1056(d)(3)(A) (2006).

14. Carrad, supra note 9, at 2 (citing Everett T. Allen et. Al., Pension Planning: Pension, Profit-Sharing, and Other Deferred Compensation PLANS 437-38 (8th ed. 1997)).

15. See supra notes 1,2 . The national rate of marriages per 1,000 persons is 6.8; the national divorce rate per 1,000 persons is 3.5 . Id.

16. See CARRAD, supra note 9, at 3, 96, 172-74; see also GARY A. SHULMAN, QUALIFIED DOMESTIC RELATIONS ORDER HANDBOOK §§ 16.01-.08 (3d ed. 2011).

17. SHULMAN, supra note $16, \S 16.01$.

18. See CARRAD, supra note 9 , at 6-7.

19. See supra notes 10-11; see also Mertens v. Hewitt Assocs., 508 U.S. 248, 251, 262 (1993) (describing ERISA as “a 'comprehensive and reticulated statute,' the product of a decade of congressional study of the Nation's private employee benefit system[,]" and "an enormously complex and detailed statute that resolved innumerable disputes between powerful competing interests" (quoting Nachman Corp. v. Pension Benefit Guar. Corp., 446 U.S. 359, 361 (1980))). 
comprehend. ${ }^{20}$ ERISA can bedevil even those who work with it on a daily basis, let alone a domestic-relations practitioner who addresses it only in connection with a divorce.

Second, ERISA grants employers wide discretion to design a variety of employee-retirement plans provided that certain minimum standards are met. ${ }^{21}$ Plans differ greatly with respect to benefits, options, terms, and procedures, which makes it difficult to create a template to use for subsequent clients. ${ }^{22}$ Third, QDROs require the application of labor law, state domestic-relations law, and federal tax law. ${ }^{23}$ Drafting a QDRO that complies with state law, federal law, and the wishes of the client is no easy task. ${ }^{24}$ Fourth, the emotions of divorcing spouses occasionally turn bitter or vindictive, which may prolong the QDRO drafting and approval process. ${ }^{25}$ After all, if a marriage that one thought would last a lifetime is coming to an end, then one of the last things a divorcee might want to see is a sizeable part of his retirement funds assigned to a former spouse.

These four factors make drafting a QDRO and getting it approved and effectuated an undertaking fraught with the potential for costly missteps. Doing it right is time consuming, frustrating, and expensive. $^{26}$ The purpose of this Article is to detail the history leading to the creation of QDROs, to explain what QDROs are, and to assist QDRO drafters so that they avoid the mistakes that are all too common in this aspect of domestic-relations practice. As difficult as understanding and drafting QDROs can be, they are not beyond the ken of lawyers who are willing to devote the time, skill, and effort to learn to prepare them correctly.

Part I of this Article will recount the status of employee pensions and retirement plans that pre-date ERISA and the effect of ERISA on

20. See generally CARRAD, supra note 9, at 11-29 (showing the comprehensive nature of ERISA and QDROs).

21. Id. at 6.

22. Id.

23. Id. at 6-7.

24. See id.

25. Id. at 7.

26. In re Gendreau, 122 F.3d 815, 819 (9th Cir. 1997). The QDRO process is time consuming, something Congress itself acknowledges. Dean, supra note 9, at 642 (citing Aaron Klein, Note, Divorce, Death, and Posthumous QDROs: When Is it Too Late for a Divorcee to Claim Pension Benefits Under ERISA? 26 CARDOzO L. REV. 1651, 1654 (2005) (stating that the process of drafting a QDRO and getting it approved is long and complex)). 
protecting the retirement-income security of American workers. Part II will explain the REA and how it filled gaps left open by ERISA. Part III will explain what a QDRO is, including definitions of key terms that are employed by those involved in the QDRO process. Part IV will identify errors and omissions in QDROs that most often lead to professional misconduct, malpractice liability, and client dissatisfaction. This Article will not only identify these pitfalls-it will offer concrete suggestions on how to avoid them. ${ }^{27}$

27. See CARRAD, supra note 9 , at $3,96,172-74$; SHULMAN, supra note 16 , $\S \S$ 16.01-.08; Paul L. Behling, Not All Domestic Relations Orders Satisfy QDRO Rules, 55 TAX’N FOR ACCT. 337, 339-42 (1995); Margaret R. Cooper, A Family Practitioner's Guide to Overcoming QDRO Phobia, 8 DEL. L. REV. 213, 214-23 (2006); Fike, supra note 9, at 235; Leslie A. Kulick, What Are the Limitations on QDROs? 61 J. Mo. B. 89, 89-91 (2005); Emily W. McBurney, Failure To Handle Qualified Domestic Relations Orders Properly, 38033 NAT’L Bus. INST. 117, 12136 (2007); Robert Preston, Strategies To Help Drafters Avoid Common Traps in Qualified Domestic Relations Orders, MATRIMONIAL STRATEGIST, Jan. 2002, at 1, 1-3; Sherwin P. Simmons \& Roberta Casper Watson, Common Errors in the Preparation of Qualified Domestic Relations Orders, FAIRSHARE: THE Matrimonial L. Monthly, Dec. 1987, at 3, 3-5; Timothy C. Voit \& James L. Parris, Fundamentals of Qualified Domestic Relations Orders, S. C. LAw. May/June 2001, at 24, 25-30; Drafting Qualified Domestic Relations Orders, 17 No. 3 Equitable Distrib. J. 25, Mar. 2000; Jerry Reiss, Dividing Pension Property: Underrated Malpractice Concerns, 16 No. 7 DivorCE LiTig. 116, July 2004; Sherwin P. Simmons, Tax Matters and QDROs in the Context of Dissolution of Marriage Proceedings, CB02 ALI-ABA1267, 1288-1301, July 8, 1996; The Top Ten QDRO Mistakes, 19 No. 6 EQUiTABle DisTRIB. J. 68, June 2002; Brett R. Turner, The Mechanics of Dividing Retirement Benefits: Recent Case Law on Preparation of Qualified Domestic Relations Orders, 10 No. 6 DivORCE LiTIG.105, June 1998; see also Paul L. Behling, Not all Domestic Relations Orders Satisfy QDRO Rules, 24 TAX'N FOR LAW. 212, 214-17 (1996); Sherwin P. Simmons, Tax Matters and QDROs in the Context of Dissolution of Marriage Proceedings, SC06 ALI-ABA 1203, 1224-38, June 30, 1997.

This Article does not address non-ERISA plans such as federal civil-service pensions, military pensions, and state- and local-government pensions, nor does it explain how to draft a QDRO in its entirety. For one interested in those subjects, these are other excellent resources: CARRAD, supra note 9; SHULMAN, supra note 16; Michael B. SNYder, QuAlified DomestiC RElations Orders (2d ed. 2011); and QDROs: The Division of Retirement Benefits Through Qualified Domestic Relations Orders, supra note 9. Some have suggested consulting “A Handbook for Attorneys on Court Ordered Retirement, Health Benefits and Life Insurance under the Civil Service Retirement Benefits, Federal Employees Retirement Benefits, Federal Employees Health Benefits, and Federal Employees Group Life Insurance Program.” This handbook is available from the United States Office of Personnel Management and can be downloaded from http://www.opm.gov 


\section{The Status of Employee Pensions and Retirement Plans BEFORE ERISA}

\section{A. The Studebaker Shutdown}

The December 9, 1963, shutdown of the Studebaker automobile plant in South Bend, Indiana, ${ }^{28}$ is widely considered to be the catalyst that led to the enactment of ERISA. ${ }^{29}$

/retire/pubs/pamphlets/ri83-116.pdf (last visited Jan. 12, 2012). I do not quarrel with those who suggest reviewing this handbook, but I do not think much good would come of it because it is 137 pages of inscrutable prose (look at the title for goodness' sake). David Clayton Carrad described it thusly, “[W]hile it is thorough and comprehensive, the handbook is written in a turgid and tedious bureaucratic style.” CARRAD, supra note 9, at 200. Emily W. McBurney echoed the sentiment: "An extraordinarily complex and confusing publication .... This handbook is notorious because it is nearly impenetrable." Emily W. McBurney, Failure to Handle Qualified Domestic Relations Orders Properly, 38033 NAT'L BuS. INST. 117, 132 (2007).

28. James A. Wooten, "The Most Glorious Story of Failure in the Business": The Studebaker-Packard Corporation and the Origins of ERISA, 49 BUFF. L. REV. 683, 683-701, 716, 726-39 (2001).

29. Private Pension Plans: Hearings Before the Subcomm. on Fiscal Pol'y of the Joint Econ. Comm., 89th Cong. 128 (1966); H.R. REP. No. 93-807, at 13, reprinted in 1974 U.S.C.C.A.N. 4670, 4680-81; Stuart N. Alperin, David H. Eisenstat, Gail A. Kreusch \& Gordon W. Netzorg, The Employee Retirement Income Security Act of 1974: Policies and Problems, 26 SYRACUSE L. REV. 541, 548, 563-64, 609, 620 (1975); Dean, supra note 9, at 646-47; Jaffke, supra note 3, at 256-57, 260-61; Sharon Reece, The Gilded Gates of Pension Protection: Amending the Anti-Alienation Provision of ERISA Section 206(d), 80 OR. L. REV. 379, 382 (2001).

The "Studebaker Incident" is not the sole reason Congress enacted ERISA. See PAul J. SCHNeIder \& BRIAN M. PinheIRo, ERISA: A COMPREHENSIVE GUIDE $\S 1.03$ (3d ed., 2008). On December 31, 1969, three persons hired by the United Mine Workers of America (UMWA) murdered Joseph "Jock" Yablonski, age fiftynine; his wife, Margaret, age fifty-nine; and their daughter, Charlotte, age twentyfive, in their Washington County, Pennsylvania, home. Richard Robbins, 1969 Yablonski murders spurred union reforms, Dec. 27, 2009, TRIBLIVE, http://www.pittsburghlive.com/x/pittsburghtrib/news/regional/s_\%20659597.html\#. The murders followed Mr. Yablonski’s loss in a vigorously contested election for the presidency of the UMWA. Id. The murders sparked a public outcry and led to an investigation by the Labor Subcommittee of the United States Senate. SCHNEIDER \& PINHEIRO, § 1.03. Because Tony Boyle, the incumbent UMWA president, faced accusations "of misuse of union health and retirement funds," the subcommittee conducted a general study of pension and welfare funds, with a special emphasis on employee protection. Id. Senator Jacob K. Javits of New York, 
In 1945, approximately one-fifth of private-sector employees had pension plans, and only a fraction had collectively bargained plans. ${ }^{30}$ In the late 1940s, the Congress of Industrial Organizations (CIO), the United Auto Workers (UAW), and the United Steelworkers led the “'Great Gold Rush of '49,'” which resulted in pensions for millions of union employees, "including production workers at the Studebaker" automobile plant and the Packard Motor Car Company. ${ }^{31}$ The push for pension benefits resulted from the postWorld War II economic boom and the aging labor force. ${ }^{32}$ During the war, "many businesses encouraged older workers" to keep working, and some businesses asked retirees to return to the work force. ${ }^{33}$ The war added significantly to unions' membership rolls, while wartime inflation eroded the purchasing power of social security. ${ }^{34}$ Consequently, many older workers delayed leaving the workforce, which resulted in "“[m]ost companies . . . hav[ing] a greater proportion of men over [age sixty-five] in their service than at any time in their history.",35

In September 1949, the UAW and Ford Motor Company agreed to a pension plan for hourly employees, and, following a strike, the steel companies followed suit. ${ }^{36}$ Studebaker adopted a definedbenefit pension plan in June 1950, and Packard Motor Car Company

a leader in the pension-reform movement in the Senate, led the investigation, and it resulted in findings that caused such an outrage that political opposition to pension reform seemed repellent. Id. Those findings included "losses caused by harsh vesting provisions, lax funding” of plans, and the lack of portable insurance programs. Id. The pension reform had its opponents, including renowned consumer advocate Ralph Nader, who opined that the ERISA bill constituted "a 'comprehensive fraud' incapable of securing its goal” because of heavy-handed editing by the Finance Committee of the United States Senate. Id. Notwithstanding the opposition, ERISA passed, and President Gerald R. Ford signed it into law on Labor Day, 1974. Id. § 1.01.

30. Wooten, supra note 28 , at 686 .

31. Id. at 686-87.

32. Id. at 687.

33. Id.

34. Id.

35. Id. (quoting M. F. Lipton, Trends in Company Pension Plans, in NAT'L Indus. Conf. BoArd, Studies in Personnel Pol'y, No. 67, at 8 (1944)) (alterations in original).

36. Wooten, supra note 28, at 690. 
did the same two months later. ${ }^{37}$ Under the Studebaker plan, employees' pension credit was calculated at the rate of $\$ 1.50$ per month for each year that an employee worked for the company up to a maximum of thirty years. ${ }^{38}$ The collectively bargained agreement set a voluntary retirement age of sixty-five and a mandatory retirement age of sixty-eight, but it allowed for early retirement at sixty if the employee had ten years of service. ${ }^{39}$ To fund the plan, Studebaker made contributions to a pension trust. ${ }^{40}$ Making those contributions, however, did not obligate Studebaker to actually pay the retirement benefits because the company limited its legal liability solely to making trust contributions. ${ }^{41}$ Contributions to the pension trusts, however, came at a cost; money paid into the trust did not get paid as wages. ${ }^{42}$ The size of these contributions depended on the magnitude of the pension benefits and the eligibility requirements employees had to meet to receive those benefits. ${ }^{43}$ The UAW and Studebaker agreement included generous pensions to retiring employees, so in order to hold down costs, the union agreed to strict eligibility requirements. ${ }^{44}$ This meant that as the auto manufacturers encountered financial difficulties in the 1950s, younger workers risked losing their pensions. ${ }^{45}$ Studebaker and Packard were prospering when they made pension agreements with the UAW, but that prosperity would prove to be short-lived. ${ }^{46}$

In 1953, the automobile industry faced a recession and the end of the postwar seller's market for cars. ${ }^{47}$ Packard lost money in the second half of 1953, and although Studebaker made a profit, it was significantly less than the prior reporting period. ${ }^{48}$ In October 1954, Packard and Studebaker merged in an effort to stanch the financial

37. Id. at 691. See Part III.A, infra, for a more detailed description of definedbenefit plans.

38. Wooten, supra note 28, at 691.

39. Id. at 691-92.

40. Id. at 692.

41. See Id.

42. Id.

43. Id.

44. Id.

45. Id.

46. Id. at $692-93$.

47. Id. at 693.

48. Id. 
hemorrhaging. ${ }^{49}$ The merger revealed the fiscal infirmities underpinning the UAW's 1949 and 1950 collectively bargained retirement plans. ${ }^{50}$ Even though those plans gave employees pension credit at the rate of $\$ 1.50$ per month for up to thirty years of service, accruing that credit did not entitle an employee to receive a pension. ${ }^{51}$ Under the Studebaker plan, an employee had to be eligible for retirement under the terms of the plan before he received a right to a pension; if the employee resigned or was terminated, then he received nothing. ${ }^{52}$ This was no accident. ${ }^{53}$ The UAW bargained for this term with the understanding that, in a plan with limited funding, a less restrictive vesting provision meant that more workers would be eligible for benefits; this meant less generous benefits for workers who qualified to receive benefits under the plan. ${ }^{54}$ The Union prioritized higher benefits for older workers to induce them to retire, resulting in more job security for younger workers. ${ }^{55}$ This increase in job security, however, meant that younger workers assumed a greater risk that they would forfeit their pensions if they did not remain employed by Studebaker until they reached age sixty with at least ten years of service. ${ }^{56}$

In 1955, the UAW negotiated a plan that made its workers fully vested in their pensions if they completed a decade of service after reaching the age of twenty-nine. ${ }^{57}$ The union sought to insulate inactive, laid off, or displaced workers from forfeiting their pension credits if they had not reached retirement age. ${ }^{58}$ This left younger workers with a greater sense of pension security, but events at Studebaker-Packard would soon show that those benefits "were less secure than they seemed." 59

In a properly funded pension plan, the employer funds pension obligations in advance by setting aside money as employees earn

\footnotetext{
49. Id. at 694.

50. Id.

51. Id.

52. Id.

53. Id. at 695.

54. Id.

55. Id.

56. See Id.

57. Id. at 697.

58. Id.

59. Id.
} 
credit. $^{60}$ The plans between the UAW and the automobile manufacturers were not funded in this fashion-dooming the plans from the start. ${ }^{61}$ Management and the unions created pension plans that promised benefits that far exceeded the resources devoted to paying them. ${ }^{62}$ Additionally, whenever the parties negotiated increases in retirement benefits, those increases created more unfunded obligations, which exacerbated the original funding problem. ${ }^{63}$ An employer's ability to fulfill its pension-funding obligations depended solely on the health of its balance sheet, so if a company experienced financial difficulty-which StudebakerPackard eventually did — the costs of funding pensions would become unsustainable. ${ }^{64}$

When Studebaker and Packard merged in October 1954, they were both in fiscal distress. ${ }^{65}$ In the third quarter of 1954, Studebaker lost nearly $\$ 14$ million, and Packard failed to meet its expenses by nearly \$12 million. ${ }^{66}$ In January and February of 1956, Packard's car sales dropped 67\% from their 1955 level. ${ }^{67}$ For much of 1956, "Studebaker-Packard teetered on the edge of bankruptcy . . . . It narrowly averted liquidation by selling its defense business and leasing several manufacturing facilities to Curtiss-Wright Corporation for about \$37 million., ${ }^{\text {"68 }}$ From that point forward, Studebaker-Packard's sole domestic automobile-production facility was the plant in South Bend, Indiana. ${ }^{69}$ In 1957, Studebaker-Packard did not lose as much money as it did in 1956; however, the company's financial condition remained precarious. ${ }^{70}$ In 1958, the economy went through another recession, and the company failed to make the first few payments on a $\$ 55$ million long-term debt. ${ }^{71}$ The prospects for the company's continued existence seemed poor, so the

\footnotetext{
60. Id. at 699.

61. See id. at 698.

62. Id.

63. Id.

64. Id.

65. Id. at 694, 698.

66. Id. at 698.

67. Id.

68. Id. at 699.

69. Id.

70. Id. at 706-07.

71. Id. at 707.
} 
company's executives decided to terminate the Packard employees' pension plan. ${ }^{72}$

Prior to the October 1954 merger, Studebaker and Packard each used pension trusts to fund their respective retirement plans. ${ }^{73}$ Following the merger, the UAW insisted that the Studebaker and Packard pension plans merge as well (which management agreed to do) so the plans combined in $1955 .{ }^{74}$ Although the pension plans merged in 1955, the pension trusts that financed the plans did not. ${ }^{75}$ "In fact, company officials maintained separate trusts with different banks serving as trustee. The firm's actuaries continued to calculate separate pension liability for the Studebaker and Packard divisions." 76 This meant that the Studebaker trust paid pensions to Studebaker retirees, and the Packard trust paid pensions to Packard retirees. ${ }^{77}$ At the end of 1957, the Packard trust had $\$ 9.6$ million in assets and approximately $\$ 27$ million in pension liabilities. ${ }^{78}$ Notwithstanding a deficit in excess of \$17 million, the Packard trust continued to pay retirees $100 \%$ of their pension benefits. ${ }^{79}$ This arrangement came to an end in January 1959 after StudebakerPackard and the local union agreed to a reduction in benefits while awaiting the outcome of a lawsuit over the validity of the termination of the Packard plan. ${ }^{80}$ In October 1959, Studebaker-Packard and the UAW settled the lawsuit, and under the terms of the agreement, Packard retirees received $85 \%$ of the benefits that they would have received before the termination of the plan. ${ }^{81}$ Retirement-eligible Packard employees who applied for a pension after September 2, 1958, received a lump-sum payment of about $\$ 43$ per year of service. $^{82}$

\footnotetext{
72. Id.

73. Id. at 709.

74. Id.

75. Id. at 709-10.

76. Id.

77. Id. at 710 .

78. Id.

79. Id. at 716 .

80. Id.

81. Id.

82. Id.
} 
In 1961, the Studebaker trust had $\$ 19.2$ million in assets and owed $\$ 22$ million in promised benefits. ${ }^{83}$ In the meantime, the company continued to struggle to make a profit. ${ }^{84}$ In 1962 and 1963, the company diversified through non-automotive acquisitions in the hope of relying less on automobile production for its economic sustenance. $^{85}$ Because of the acquisitions, the company showed a profit in 1962, but not in the automotive division. ${ }^{86}$ Although 1963 proved to be a banner year for the car industry, Studebaker-Packard's automotive division's losses in the first half of the year exceeded the profits generated by all of the company's other divisions by $\$ 7.5$ million. ${ }^{87}$ On December 9, 1963, Studebaker-Packard announced the closing of the South Bend, Indiana, plant. ${ }^{88}$ Six weeks later, the company announced that Studebaker retirees and retirement-eligible employees would receive their full pension benefits. ${ }^{89}$ Other Studebaker workers would not be as fortunate. ${ }^{90}$ The pension liabilities of the Studebaker pension trust exceeded its assets by $\$ 15$ million, which meant that the retirement funds of 4,392 existing and former Studebaker employees stood to be extinguished. ${ }^{91}$

Leaders of the local union stated that the pension plan represented a private promise by the company that it had a social, moral, and equitable obligation to keep. ${ }^{92}$ When the company did not keep that promise, the union and its members had little recourse. ${ }^{93}$ On October 15,1964 , the company and the local union entered into an agreement that terminated the Studebaker pension plan. ${ }^{94}$ The agreement called for current retirees and workers over the age of sixty who were

83. Id. at 728 .

84. Id. at 729 .

85. Id.

86. Id.

87. Id. at $729-30$.

88. Id.

89. Id.

90. See id.

91. Id.

92. Id. at $730-31$.

93. Id. "[T] collective-bargaining agreement with [the local union].” Id. Even if the union had prevailed, it would have been a Pyrrhic victory because the pension trust simply lacked the funds necessary to pay all of its obligations. Id. The trust was judgmentproof. Id.

94. Id. 
eligible to retire to receive $100 \%$ of their pension benefits. ${ }^{95}$ Workers under the age of sixty, some of whom had worked for the company for forty years, received a lump sum worth approximately $15 \%$ of the full value of their pension. ${ }^{96}$ Workers under age forty and those who were not fully vested in their retirement plans received nothing. ${ }^{97}$

The shuttering of the Studebaker plant has been described as " "the most glorious story of failure in the business'” because it pushed the topic of pension-termination insurance squarely into the public debate on pension reform. ${ }^{98}$

\section{B. The Long, Wending Path to Pension-Termination Insurance}

Because of the flawed funding mechanism and the lack of insurance that could be used to cover losses, neither the UAW nor the government could do much to stop the Studebaker pension plan from defaulting on its obligations to the thousands of workers who relied on the promise of retirement-income security. ${ }^{99} \mathrm{~A}$ few years before the collapse of the plan, public officials and private-sector pension experts considered federal legislative proposals to protect workers in private pension plans. ${ }^{100}$ Specifically, this legislation proposed that insurance "would pay the difference between the cost of some or all of the benefits [a] plan promised and the value of . . plan assets available to pay those benefits." ${ }^{101}$ In 1958, Congress began regulating private-sector employee-benefit plans when it passed the Welfare and Pension Plans Disclosure Act. ${ }^{102}$ In March 1962, President John F. Kennedy established the President's Committee on Corporate Pension Funds to study the country's private pension plans. ${ }^{103}$ Union leaders urged the Committee to recommend the

95. Id.

96. Id.

97. Id.

98. Id. at 686.

99. See id. at 732 .

100. Id.

101. Id. at 723 .

102. Welfare and Pension Plans Disclosure Act, Pub. L. No. 85-836, 72 Stat. 997 (repealed 1976). Congress limited the scope of this law to disclosure only. Jaffke, supra note 3 , at 260 . The law did not set minimums with respect to funding or employee participation, nor did it establish fiduciary responsibilities for plan administrators. Id.

103. Wooten, supra note 28, at 732. 
establishment of pension-termination insurance, but " $[\mathrm{w}] \mathrm{hen}$ the Committee submitted an interim report in November 1962, it did not recommend legislation to create [pension-termination insurance] because of concerns about the feasibility of insuring private pensions." "104 The "Committee did, however, urge further study of the idea[, and i]n January 1963 [President] Kennedy [tasked] another committee - the President's Labor-Management Advisory Committee - to review the report of the Committee on Corporate Pension Funds."105 This committee did not recommend establishing pension-termination insurance. ${ }^{106}$

Refusing to let a crisis go to waste, union officials recognized that the publicity from the shutdown of the Studebaker plant provided an excellent opportunity to revive the issue of pension-termination insurance; therefore, they persuaded Walter Reuther, the UAW president and a member of the Labor Management Advisory Committee, to raise the South Bend shutdown and the need for pension-termination insurance with President Lyndon B. Johnson at a January 1964 meeting. ${ }^{107}$ President Johnson did not embrace the idea of insurance because he needed business leaders' support for his election campaign, and he did not want to expend political capital on a proposal that might antagonize them. ${ }^{108}$

Having failed to persuade President Johnson to champion their cause, proponents of pension-termination insurance turned to Senator Rupert Vance Hartke of Indiana. ${ }^{109}$ Senator Hartke introduced the Federal Reinsurance of Private Pensions Act on August 3, 1964, ${ }^{110}$ suggesting that the Studebaker plant shutdown proved that workers needed pension-termination insurance. ${ }^{111}$ The shutdown played a prominent role in the discussions of pension reform and pension-

104. Id. at 733 .

105. Id.

106. Id.

107. Id. at 733-34.

108. Id. at 734 .

109. Id.

110. S. 3071, 88th Cong. (1964); Wooten, supra note 28, at 734-35. The term "reinsurance" in the title is a misnomer. Id. at 734. The proposal was not intended to "reinsure" anything. Id. at 734. Union officials insisted that the term be used to make the proposal more politically palatable. Id. at 734-35.

111. Wooten, supra note 28, at 735. 
termination insurance. ${ }^{112}$ Having comfortably won the 1964 election, ${ }^{113}$ President "Johnson['s] administration [started] preparing pension reform legislation in 1966" that included termination insurance. ${ }^{114}$ In 1967, Senator Jacob K. Javits of New York introduced a bill similar to a modified version of Senator Hartke's 1964 bill. ${ }^{115}$ In 1968, a bill sponsored by the Department of Labor was introduced that included pension-termination insurance. ${ }^{116}$ In 1970, a staff member of the House Committee on Education and Labor said that the Studebaker shutdown spurred Congressional action in the private-pension arena like the mine explosion in Farmington, West Virginia, had provided an impetus for Congress to enact the Federal Coal Mine Health and Safety Act of 1969. A labor lobbyist compared it to "the Triangle fire episode that led to the [regulation of] sweatshops in the garment industry."”117 Notwithstanding all of the legislative and political activity around the issues of the Studebaker shutdown, pension reform, and pensiontermination insurance, ERISA as we know it did not become the law of the land until November 2, 1974—more than a decade after the collapse of the Studebaker plant and its employees' pension plan. ${ }^{118}$

112. Id. (citing Michael Allen, The Studebaker Incident and its Influence on the Private Pension Plan Reform Movement, in JoHn H. LANGBEIN \& BRUCE A. WOLK, Pension and Employee Benefit Law 68, 70 (3d ed. 2000)).

113. On November 3, 1964, President Johnson defeated Senator Barry Goldwater of Arizona 486 electoral votes to fifty-two. Nat'l Archives \& Record Admin., Historical Election Results, available at http://www.archives.gov/federalregister/electoral-college/scores.html\#1964 (last visited Jan. 12, 2012). President Johnson received 43,129,566 (61.34\%) popular votes to Senator Goldwater's 27,178,188 (38.66\%) and won forty-four states to Senator Goldwater's six (Alabama, Arizona, Georgia, Louisiana, Mississippi, and South Carolina). Nat'l Archives \& Record Admin., Historical Election Results, available at http://www.archives.gov/federal-register/electoral-

college/votes/1965_1969.html\#1964 (last visited Jan. 12, 2012).

114. Wooten, supra note 28, at 736.

115. Id.; S. 1103, 90th Cong. (1967).

116. Wooten, supra note 28, at 736; S. 3421, 90th Cong. (1968).

117. Wooten, supra note 28, at 736 (quoting Private Welfare and Pension Plan Legislation: Hearings on H.R. 1045, H.R. 1046, and H.R. 16462 Before the General Subcomm. on Labor of the H. Comm. on Education and Labor, 91st Cong. 155 (1970)).

118. See Wooten, supra note 28, at 739. 


\section{The Enactment of ERISA}

The Studebaker plant closure was a searing example of what could happen to employee pensions in a completely unregulated environment. That environment produced a number of problems including little to no disclosure to employees of what pension rights they had and the termination of pension plans due to employer bankruptcy or poor economic performance. ${ }^{119}$ Employers were allowed to design plans making benefits conditional gifts forfeitable at their whim, ${ }^{120}$ and some retained the right to cut off pension benefits of former workers if the former employer did not approve of their actions. ${ }^{121}$ The "law" of retirement plans often consisted of little more than a handshake. ${ }^{122}$ An employer could terminate a worker on the cusp of pension eligibility solely to avoid paying the pension. ${ }^{123}$ Adding insult to injury, the employer could do this with legal impunity.

In response to these and other issues such as administrative ineptness, corruption, graft, and the lack of uniformity in how states regulated pensions, Congress enacted ERISA. ${ }^{124}$ Congress stated that ERISA's most important purpose was to provide American workers with a financially secure retirement. ${ }^{125}$

Congress divided ERISA into multiple parts, all of which were designed to protect plan participants ${ }^{126}$ and their beneficiaries. ${ }^{127}$ One

119. CARRAD, supra note 9 , at 1 .

120. Reece, supra note 29 , at 382.

121. See CARRAD, supra note 9 , at 1 .

122. Dean, supra note 9, at 647-48 (citing SNYDER, supra note 27, at 4).

123. CARRAD, supra note 9 , at 1 .

124. Ablamis v. Roper, 937 F.2d 1450, 1452-53 (9th Cir. 1991) (citing H.R. REP. No. 93-1280, at 7 (1974) (Conf. Rep.), reprinted in 1974 U.S.C.C.A.N. 4639) ("Congress enacted ERISA to . . . ensure 'the continued well-being and security of millions of employees and their dependents' who rely upon retirement plans.” Id.); H.R. REP. No. 533 (1974), reprinted in 1974 U.S.C.C.A.N. 4639-43; Julie Ann Barbo, Ablamis v. Roper: Preemption of the NonEmployee Spouse's Community Property Rights in ERISA Pension Plans, 49 WASH. \& LEE L. REV. 1085, 1086-87 (1992) (explaining that before ERISA, no federal regulation of pension plans existed, state regulation varied widely, and many employees lost their expected retirement benefits in this environment).

125. S. REP. No. 93-127 (1974), reprinted in 1974 U.S.C.C.A.N. 4838, 4849.

126. A participant is "any employee or former employee of any employer, or any member or former member of an employee organization, who is or may become eligible to receive a benefit of any type from an employee benefit plan [that] covers 
part requires plan administrators to regularly make certain disclosures and reports to plan participants and their beneficiaries. ${ }^{128}$ These disclosure and reporting requirements are enforced by the Department of Labor Employee Benefits Security Administration. ${ }^{129}$ A second part limits the amount of time that an employee must wait before he is allowed to participate in an employer's pension plan. ${ }^{130}$ A third part sets minimum funding requirements for plans. ${ }^{131} \mathrm{~A}$ fourth part imposes fiduciary duties on plan administrators, which require them to act like prudent investors. ${ }^{132}$ These fiduciary duties "include providing adequate benefits to plan participants, minimizing [plan] expenses, and diversifying [plan] investments." ${ }^{133}$ Finally, a fifth part contains enforcement and administrative rules. ${ }^{134}$

The enactment of ERISA included the creation of the Pension Benefit Guaranty Corporation (PBGC), a public, non-profit

employees of such employer or members of such organization, or whose beneficiaries may be eligible to receive any such benefit.” 29 U.S.C. § 1002(7) (2006).

127. A beneficiary is "a person designated by a participant, or by the terms of an employee benefit plan, who is or may become entitled to a benefit thereunder." 29 U.S.C. § 1002(8).

128. 29 U.S.C. $\S \S ~ 1021-1031 ;$ Jaffke, supra note 3, at 261; Reece, supra note 29, at 382-83. The following can serve as the administrator of the plan: (1) a person designated under the plan itself; (2) the plan sponsor; (3) the employer; or (4) someone chosen by the Secretary of Labor. § 1002(16); Dean, supra note 9, at 648. "The administrator must provide an annual report that includes a financial statement and [an] opinion” by an independent public accountant that the statement conforms to generally accepted auditing standards. $\S 1023$; Dean, supra note 9, at 648. The annual report must also state the "number of employees in the plan, [the name] and address[] of any fiduciary, and an actuarial statement.” $\S 1023(c)(1)$; Dean, supra note 9, at 648. "The administrator must also provide a plan description to all participants and beneficiaries of the plan . . .” $\S 1023$; Dean, supra note 9, at 649. Upon written request by a plan participant or beneficiary, the administrator must provide "a written statement of what benefits have accrued or will become non-forfeitable” under the plan. § 1025; Dean, supra note 9, at 649.

129. On May 16, 1997, the Pension and Welfare Benefits Administration became the Employee Benefits Security Administration. 5 C.F.R. $§ 2641$, app. B (2007); Dean, supra note 9, at 649.

130. 29 U.S.C. $\S 1052(a)(1)(A)(2006)$.

131. 29 U.S.C. $\S 1082$.

132. 29 U.S.C. $\S 1104$.

133. 29 U.S.C. $\S \S ~ 1101-1114$; Dean, supra note 9, n.56, at 649.

134. 29 U.S.C. §§ 1131-1147; Jaffke, supra note 3, at 261; Reece, supra note 29, at 382-83. 
corporation that guarantees all nonforfeitable benefits under ERISAgoverned defined-benefit plans. ${ }^{135}$ The PBGC has enforcement powers, including the authority to investigate pension plans and to sue for violations of ERISA. ${ }^{136}$ It can also collect payments from employers who terminate pension plans with outstanding benefit liabilities. $^{137}$ The establishment of the PBGC is the pensiontermination insurance for which so many toiled long before and after the Studebaker plant closure. ${ }^{138}$

ERISA covers employee pension-benefit plans ${ }^{139}$ and employee welfare-benefit plans. ${ }^{140}$ Most workers participate in defined-benefit plans, ${ }^{141}$ defined-contribution plans, ${ }^{142}$ and cash-balance plans. ${ }^{143}$ The specifics of each of these plans will be discussed in Part IV of this Article. However, ERISA does not cover all pension or

135. 29 U.S.C. $\S \S 1302,1303$; Dean, supra note 9, at 648; The PBGC insures the defined-benefit pensions of an employer's workers if the benefit plan is underfunded and the company files bankruptcy or ceases to do business. U.S. Gov'T ACCOUnTABILITY OfFICE, GAO/HEHS-99-37R, PBGC'S FINANCIAL CONDITION (Nov. 9, 1994). The PBGC becomes the trustee of the plan, invests the assets of the plan, and pays benefits - albeit at a lesser amount than would be the case if the plan were not underfunded-to the plan's participants. Id.

136. 29 U.S.C. $\S \S 1302-1303$.

137. 29 U.S.C. §§ 1361-1368. Dean, supra note 9, at 650.

138. Wooten, supra note 28 , at 736-39.

139. 29 U.S.C. $\S 1002(2)(A)$. An employee pension-benefit plan is a plan sponsored by an employer to provide either retirement income or a deferral of income until the termination of employment or beyond. Id.

140. 29 U.S.C. § 1002(1). Section 1002(1) defines an employee welfare-benefit plan as follows:

[A]ny plan, fund, or program that was heretofore or is hereafter established or maintained by an employer or by an employee organization, or by both, to the extent that such plan, fund, or program was established or is maintained for the purpose of providing for its participants or their beneficiaries, through the purchase of insurance or otherwise, (A) medical, surgical, or hospital care or benefits, or benefits in the event of sickness, accident, disability, death or unemployment, or vacation benefits, apprenticeship or other training programs, or day care centers,

Id. scholarship funds, or prepaid legal services . . . .

141. 29 U.S.C. § 1002(34).

142. 29 U.S.C. § 1002(35).

143. 29 U.S.C. $\S 1054(\mathrm{~b})(5)(A)-(G)$. 
retirement plans. ${ }^{144}$ It does not cover military ${ }^{145}$ or government ${ }^{146}$ retirement plans. ${ }^{147}$ Likewise, plans that are maintained for workers' compensation or unemployment, ${ }^{148}$ church plans, or Individual Retirement Accounts are not covered. ${ }^{149}$

Two parts of ERISA specifically relate to QDROs: the spendthrift provision $^{150}$ and the preemption provision. ${ }^{151}$

\section{ERISA’s Spendthrift Provision}

Employers have an incentive to establish and maintain plans covered by ERISA because it allows them to take tax deductions on the contributions that they make on behalf of participating employees. $^{152}$ Participating employees have this same incentive because the contributions that they make to their plans and the earnings on those contributions are tax-deferred. ${ }^{153}$

144. Dean, supra note 9 , at 652.

145. Military plans are governed by the Uniformed Services Former Spouses' Protection Act, which is codified as 10 U.S.C. $§ 1408$ (2006).

146. Federal government employees who are not members of the armed services are covered by either the Federal Employees Retirement System or the Civil Service Retirement System. 5 U.S.C. §§ 8345(j), 8467; 5 C.F.R. §§ 838.101-.1018. Railroad employees who are not employed by private railroads are covered by the Railroad Retirement Act of 1974, codified as 45 U.S.C. §§ 231-231v. CARRAD, supra note 9, at 226-28.

147. ERISA exempts government plans from its coverage. 29 U.S.C. § 1003(b)(1). Government plans include those "established or maintained for its employees by the Government of the United States, by the government of any State or political subdivision thereof, or by any agency or instrumentality of any of the foregoing.” 29 U.S.C. § 1002(32) (2006). On the other hand, public educational institutions, such as state universities, may establish and maintain ERISA-covered plans for their employees pursuant to 26 U.S.C. $\S$ 403(b)(1)(A)(i)-(ii). These are known as 403(b) plans. See infra § III.B.

148. 29 U.S.C. $\S 1003(\mathrm{~b})(3)$.

149. 29 U.S.C. $\S 1003(\mathrm{~b})(2)$. Church plans can elect to be covered, which some may find desirable if their plans lack rules for dividing pensions in divorce proceedings. Dean, supra note 9, at 652 (citing GARY A. SHULMAN \& DAVID I. Kelley, Dividing Pensions IN Divorce § 21.1 (2d ed. 1999)). Individual Retirement Accounts are not governed by ERISA. 29 U.S.C. $\S$ 1051(6).

150. 29 U.S.C. $\S 1056(d)(1)$. "Each pension plan shall provide that benefits provided under the plan may not be assigned or alienated." Id.

151. 29 U.S.C. $§ 1144(a)$. Section 1144(a) states in part that ERISA supersedes all state laws relating to any employee-benefit plan. Id.

152. 26 U.S.C. $\S 404$.

153. 26 U.S.C. $\S 402 A(a)$. 
For employers to take advantage of the tax benefits afforded under ERISA, their retirement plans must expressly prohibit the assignment or alienation of benefits provided to employees. ${ }^{154}$ Congress included this provision to protect employees from their own financial imprudence and to protect them from others who might use their retirement plans as a means to retaliate against them-as employers frequently did before the enactment of ERISA. ${ }^{155}$ Congress intended that the employee's accrued benefits would actually be available at retirement; therefore, "Neither the employer nor the employee can assign or alienate the benefits." ${ }^{\prime 56}$ The Internal Revenue Service (IRS) ${ }^{157}$ will not consider a plan qualified under ERISA unless the plan explicitly provides that benefits cannot be assigned at law or in equity, alienated, or subject to attachment, garnishment, levy, execution, or other legal or equitable process. ${ }^{158}$ This spendthrift provision has teeth, as reflected in some significant Supreme Court decisions. ${ }^{159}$

One such decision is Guidry v. Sheet Metal Workers National Pension Fund. ${ }^{160}$ In Guidry, a union official "pleaded guilty to embezzling funds from his union." "161 "The union obtained a judgment against him for $\$ 275,000$. . . [and t]he District Court

154. See 29 U.S.C. § 1056(d)(1).

155. Boggs v. Boggs, 520 U.S. 833, 863-64 (1997) (citing Guidry v. Sheet Metal Workers Nat'l Pension Fund, 493 U.S. 365, 376 (1990)). Congress included an anti-alienation provision in ERISA to protect workers' retirement income. Id.; Am. Tel. \& Tel. Co. v. Merry, 592 F.2d 118, 124 (2d Cir. 1979). The purpose of the anti-alienation and anti-assignment provision "is to protect an employee from his own financial improvidence in dealings with third parties." Id.; Reece, supra note 29, at 383, 386-88.

156. Reece, supra note 29, at 387.

157. Jurisdiction over ERISA is divided between the Department of Labor and the IRS; however, the Department of Labor has jurisdiction over QDROs. I.R.C. § 401(n); 29 U.S.C. §§ 1056(d)(3), 1201-1242 (2006). The Department of Labor originally had "[t]he authority to issue regulations for the funding and vesting of ERISA plans," but in 1978, President Jimmy Carter issued an executive order transferring this authority to the IRS. Dean, supra note 9, at 649-50 (citing SNYDER, supra note 27, § 1:4).

158. 26 U.S.C. § 401(a)(13) (2006);; Treas. Reg. § 1.401(a)-13(b)(1) (2011);

Reece, supra note 29, at 386.

159. Patterson v. Shumate, 504 U.S. 753 (1992); Guidry, 493 U.S. at 376.

160. 493 U.S. 365.

161. Id. at 367 . 
imposed a constructive trust on [his] pension benefits."162 The union official appealed, arguing that the constructive trust violated the antialienation and anti-assignment provisions of ERISA. ${ }^{163}$ The Supreme Court agreed with the union official and declined to create a criminalconduct exception to ERISA's anti-alienation clause. ${ }^{164}$ The Court stated that Congress made the "policy choice . . . to safeguard a stream of income for pensioners and their dependents," even if doing so meant preventing parties wronged by pensioners from securing relief. ${ }^{165}$ The Court acknowledged that ERISA's spendthrift provision would "hinder the collection of . . . lawful debt[s]," but stated that if an exception to that provision was to be created, then Congress, rather than the Court, should create it. ${ }^{166}$

In Patterson v. Shumate, the Court considered the question of whether a bankrupt debtor's pension worth $\$ 250,000$ had to be included in his bankruptcy estate and thus reachable by his creditors. ${ }^{167}$ The debtor argued that his pension should be excluded from the bankruptcy estate based on ERISA's spendthrift clause and 11 U.S.C. $\S 541(\mathrm{c})(2),{ }^{168}$ a section of the Bankruptcy Code that excludes from the bankruptcy estate trusts that have transfer restrictions imposed on them under the "applicable non-bankruptcy law." 169 The district court disagreed and held that "applicable nonbankruptcy law" meant state law only, and that under Virginia law, the debtor's pension did not qualify as a spendthrift trust. ${ }^{170}$ The United States Court of Appeals for the Fourth Circuit reversed, and held that the phrase "applicable non-bankruptcy law" included

162. Id. at 367-70 (citing Guidry v. Sheet Metal Workers Nat'l Pension Fund, 641 F. Supp. 360, 360-63 (D. Colo. 1986)). The United States Court of Appeals for the Tenth Circuit affirmed the district-court judgment. Id. at 370-71 (citing Guidry v. Sheet Metal Workers Nat'l Pension Fund, 856 F.2d 1457, 1460-61 (10th Cir. 1988)).

163. Id. at 367.

164. Id. at 376 .

165. Id.

166. Id. at 376-77.

167. Patterson v. Shumate, 504 U.S. 753, 755-57 (1992).

168. 11 U.S.C. $§ 541(c)(2)$ (2006) (stating that "a restriction on the transfer of a beneficial interest of the debtor in a trust that is enforceable under applicable nonbankruptcy law is enforceable in a [bankruptcy proceeding]”).

169. Patterson, 504 U.S. at 755-57.

170. Id. (citing Creasy v. Coleman Furniture Corp., 83 B.R. 404, 406 (W.D. Va. 1988)). 
ERISA's non-alienation provision and that it restricted the transfer of the debtor's pension to the bankruptcy estate. ${ }^{171}$ The Supreme Court affirmed the Fourth Circuit's decision and noted that it would be inconsistent to allow a creditor to reach a debtor's ERISA-covered pension in a bankruptcy proceeding but disallow that same creditor access to that pension in a garnishment or collection action outside of a bankruptcy case. ${ }^{172}$ The Court resolved this inconsistency in favor of shielding debtors' ERISA pensions from the reach of creditors, even in bankruptcy proceedings. ${ }^{173}$

At bottom, ERISA's spendthrift provision makes an employee's pension benefits off limits to creditors, even those who became creditors as a result of wrongs committed by the pensioner. ${ }^{174}$ Creditors, however, are not the only parties left in the lurch by ERISA's spendthrift provision. Before the enactment of the REA, divorced persons could be treated like creditors and be denied their marital share of their former spouses' retirement plans based on ERISA's spendthrift and preemption provisions. ${ }^{175}$

171. Id. at 756-57 (citing Shumate v. Patterson, 943 F.2d 362, 365-66 (4th Cir. 1991)).

172. 504 U.S. at 764 (citing Donna Litman Seiden, Chapter 7 Cases: Do ERISA and the Bankruptcy Code Conflict as to Whether a Debtor's Interest in or Rights Under a Qualified Plan can be Used to Pay Claims?, 61 AM. BANKR. L.J. 301, 317 (1987)).

173. Id. at 764-65.

174. See supra notes $152-73$ and accompanying text. "The anti-alienation provision . . . 'bespeak[s] a pension law protective policy of special intensity: Retirement funds shall remain inviolate until retirement.'” Boggs v. Boggs, 520 U.S. 833, 851 (1997) (quoting LANGBEIN, supra note 113, at 547). Reece, supra note 29, at 408. Even though a civil jury found O.J. Simpson liable for the deaths of Nicole Brown Simpson and Ronald Goldman, their estates cannot touch his major source of wealth to collect their judgment: two pension and retirement funds valued at a minimum of $\$ 2.5$ million. Id. ERISA's anti-alienation and anti-assignment provisions render these funds off limits to judgment creditors. Id.

175. Pub. L. No. 98-387, reprinted in 1984 U.S.C.C.A.N. (98 Stat. 1426) 2547, 2549, 2564-68. 


\section{ERISA Preemption}

Federal legislation can preempt state legislation. ${ }^{176}$ The basis of Congress's preemption authority is the Supremacy Clause, ${ }^{177}$ and when preemption issues arise, a court must determine whether Congress intended to trump the state's law-making authority. ${ }^{178}$ Congress may preempt state law explicitly or implicitly. State laws have to yield, regardless of the particular method that Congress chooses when Congress seeks to be the exclusive legislative authority in a given arena. ${ }^{179}$

If an act of Congress does not contain clear preemptive language, then preemption may nevertheless be inferred in three instances: first, if " " $[\mathrm{t}] \mathrm{he}$ scheme of federal regulation [is] so pervasive [that it is reasonable to infer] that Congress left no room for the states to supplement it”'; second, if the congressional enactment touches "“a field [where] the federal interest is so dominant that the federal system will be assumed to preclude enforcement of state laws on the same subject"”; and third, if “'the object sought to be obtained by . . . federal law and the character of obligations imposed by it . . . reveal[s] the same purpose"” as state law. ${ }^{180}$ "Even where Congress has not completely displaced state regulation in a specific area, state law is nullified to the extent that it actually conflicts with federal law."181 "Such . . . conflict[s] arise[] when 'compliance with . . . federal and state regulations is a physical impossibility,' or when

176. Pac. Gas \& Elec. Co. v. State Energy Res. Conservation \& Dev. Comm'n, 461 U.S. 190, 203 (1983) (citing Jones v. Rath Packing Co., 430 U.S. 519, 525 (1977)).

177. U.S. CONST. art. VI, cl. 2 states:

This Constitution, and the Laws of the United States which shall be made in Pursuance thereof; and all Treaties made, or which shall be made, under the Authority of the United States, shall be the supreme Law of the Land; and the Judges in every State shall be bound thereby, any Thing in the Constitution or Laws of any State to the Contrary notwithstanding.

Id.

178. Fid. Fed. Sav. \& Loan Ass'n v. de la Cuesta, 458 U.S. 141, 152-53 (1982).

179. Id. at 153 (citing Jones v. Rath Packing Co., 430 U.S. 519, 525 (1977)).

180. Id. (quoting Rice v. Santa Fe Elevator Corp., 331 U.S. 218, 230 (1947)).

181. Id. 
state law 'stands as an obstacle to the accomplishment and execution of the full purposes and objectives of Congress.",182

Given "the centrality of pension . . . plans in the national economy, and their importance to the financial security of the Nation's work force," Congress sought to bring uniformity to the regulation of employee-benefit plans. ${ }^{183}$ Congress accomplished this uniformity by structuring ERISA to expressly preempt all state laws related to employee-benefit plans. ${ }^{184}$ If a federal law contains an express preemption clause-as ERISA does-then a court still must determine whether Congress intended federal law to occupy the entire field or if state and federal law are at loggerheads. ${ }^{185}$ The former type of preemption is called field preemption, and it applies when Congress assumes exclusive jurisdiction to regulate a subject. ${ }^{186}$ When it does, state regulation is not allowed-even if the state regulation is consistent with federal regulation. ${ }^{187}$ This latter type is called conflict preemption, and under it "states possess concurrent authority with the federal government to regulate the subject area." "188 If state law and federal law conflict, then "the Supremacy Clause dictates that the federal law will prevail; otherwise, states may enforce their consistent and supplemental laws in the federally regulated area." 189 The case of Boggs $v$. Boggs presented the Supreme Court with the question of what type of

182. 458 U.S. at 153 (citing Jones v. Rath Packing Co., 430 U.S. 519, 526 (1977); Florida Lime \& Avocado Growers, Inc. v. Paul, 373 U.S. 132, 142-43 (1963); Bethlehem Steel Co. v. New York Labor Relations Bd., 330 U.S. 767, 773 (1947); Hines v. Davidowitz, 312 U.S. 52, 67 (1941)).

183. Boggs v. Boggs, 502 U.S. 833, 839 (1997); Jaffke, supra note 3, at 262.

184. Boggs, 520 U.S. at 841 (citing 29 U.S.C. § 1144(a) (1975)).

185. Altria Group, Inc. v. Good, 555 U.S. 70, 76 (2008) (citing Freightliner Corp. v. Myrick, 514 U.S. 280, 287 (1995)).

186. Rice v. Santa Fe Elevator Corp., 331 U.S. 218, 229-31 (1947); Jaffke, supra note 3, at 263 (citing Donald T. Bogan, Protecting Patient Rights Despite ERISA: Will the Supreme Court Allow States To Regulate Managed Care?, 74 TuL. L. REV. 951, 961 (2000)).

187. Rice, 331 U.S. at 229-31; Jaffke, supra note 3, at 263 (citing Bogan, supra note 186 , at 961$)$.

188. Rice, 331 U.S. at 229-31; Jaffke, supra note 3, at 263 (citing Bogan, supra note 186 , at 961-62).

189. Rice, 331 U.S. at 229-31; Jaffke, supra note 3, at 263 (citing Bogan, supra note 186 , at 962). 
preemption, if any, applies under ERISA with respect to state community-property and succession laws. ${ }^{190}$

Isaac Boggs retired from South Central Bell in 1985 after thirtysix years of service. ${ }^{191}$ When he started at the company, Mr. Boggs was married to Dorothy Boggs and remained so until she died in 1979. ${ }^{192}$ Their marriage produced three sons. ${ }^{193}$ Following Dorothy's death, Mr. Boggs married Sandra Boggs and remained married to her until he died in 1989. ${ }^{194}$ Mr. Boggs retired in 1985 and received a lump-sum distribution from his South Central Bell retirement plan in the amount of $\$ 151,628.94$, which he rolled over into an individual retirement account (IRA). ${ }^{195}$ When he died, the account contained $\$ 180,778.05$. $^{196}$ In addition to the lump-sum payment, Mr. Boggs received ninety-six shares of stock and a monthly annuity payment of $\$ 1,777.67 .^{197}$

Before she died, Dorothy executed a will that left Mr. Boggs onethird of her estate and a life estate in the remaining two-thirds. ${ }^{198}$ She left ownership in the remaining two-thirds to her three sons, subject to their father's life estate. ${ }^{199}$ Under Louisiana law, Dorothy's will controlled the distribution of her community-property ${ }^{200}$ "interest in [Mr. Boggs’s] undistributed pension plan benefits.” 201 In 1980, a Louisiana state court determined that her interest in those benefits had a value of $\$ 21,194.29 .^{202}$ Sandra challenged the validity of Dorothy's testamentary transfer, arguing that Mr. Boggs's will left

190. 520 U.S. 833, 835 (1997).

191. Id. at 836.

192. Id.

193. Id.

194. Id.

195. Id.

196. Id.

197. Id.; see also Black's LAW DictionaRY 105 (9th ed. 2009) (defining annuity as "[a]n obligation to pay a stated sum, usually monthly or annually, to a stated recipient"). See generally CARRAD, supra note 9, at 70 (explaining that the length of time an annuity is paid can be tied to the lifetime of one person or multiple persons).

198. 520 U.S. at 836

199. Id. at 836-37.

200. Id. at 840; see also $1 \mathrm{~W}$. DE FUNIAK, PRINCIPLES OF COMMUNITY PROPERTY 11, 85-89 (1943) (explaining that Louisiana is a community-property state).

201. 520 U.S. at 837.

202. Id. 
his undistributed benefits to her, and that she was entitled to them under ERISA. ${ }^{203}$ Mr. Boggs's will left Sandra the family home and a life estate in the remainder of his estate. ${ }^{204}$ He also left his sons the remainder of his estate, subject to Sandra's life estate. ${ }^{205}$

Following their father's death, two of Mr. Boggs's sons filed a state-court action seeking a judgment awarding them a portion of the IRA, the stock, and the monthly annuity payments that Mr. Boggs received during his life. ${ }^{206}$ They also requested that the court award them the survivor-annuity payments that Sandra had already been paid as well as future annuity payments that would be paid to her. ${ }^{207}$ Sandra filed a complaint in federal district court seeking a declaration that ERISA preempted Louisiana law to the extent that it recognized the sons' claim to the survivor's annuity. ${ }^{208}$ The sons filed a motion for summary judgment, and the court granted it. It found "that, under Louisiana community property law, Dorothy had an ownership interest in [Mr. Boggs's] pension plan benefits [that accrued] during their marriage."209 The court further held that Dorothy's ownership interest did not contravene ERISA's spendthrift provision because "Congress did not intend [ERISA] to alter traditional familial or support obligations." 210 The court did not consider Dorothy's testamentary transfer to be an assignment or alienation of the pension benefits because she acquired her right to those benefits under community-property law, not by a transfer from Mr. Boggs. ${ }^{211}$ The United States Court of Appeals for the Fifth Circuit affirmed, agreeing with the district court that Dorothy's testamentary transfer

203. Id. Sandra relied on 29 U.S.C. $§ ~ 1055(a)(1)$ (2006), the part of ERISA that creates a qualified joint-and-survivor annuity, which requires that when a plan participant dies after his annuity starts, the accrued benefit owed to him must be paid to his surviving spouse as long as the surviving spouse did not execute a written waiver of her right to the survivor's annuity. $\S \S 1055(c)(2) ; 1055(d)(1)$. The surviving spouse receives at least one-half of the amount of the annuity that the participant received during his life. § 1055(d)(1).

204. 520 U.S. at 837.

205. Id.

206. Id.

207. Id.

208. Id. at 837, 838 (citing Boggs v. Boggs, 849 F. Supp. 462 (E.D. La. 1994)).

209. Id.

210. Id. at 838 (citing 29 U.S.C. § 1056(d)(1) (2006)).

211. Id. 
did not constitute "a prohibited assignment or alienation."212 The Fifth Circuit's decision conflicted with Ablamis v. Roper, a Ninth Circuit case that "held that ERISA pre-empts a testamentary transfer by [the spouse of a plan participant] of her community property interest in undistributed pension plan benefits." ${ }^{213}$ This circuit split presented the Supreme Court of the United States with the question of whether and how ERISA preempts state community-property and succession laws. ${ }^{214}$

The Court ruled that ERISA did preempt state communityproperty law using a conflict-preemption analysis. ${ }^{215}$ The Court began by analyzing whether Louisiana's community-property and succession laws conflicted with ERISA. ${ }^{216}$ The Court concluded that they did, so it did not reach the question of whether field preemption applied. $^{217}$ The Court determined that the objective of the qualified joint-and-survivor annuity provision of ERISA ${ }^{218}$ would be rendered

212. Id. (citing Boggs v. Boggs, 82 F.3d 90 (5th Cir. 1996)).

213. Id. at 839 (citing Ablamis v. Roper, 937 F.2d 1450 (9th Cir. 1991)).

214. Id.

215. Id. at 841.

216. Id.

217. Id. In the same term that the Court decided Boggs, it decided two other ERISA-preemption cases. See De Buono v. NYSA-ILA Med. \& Clinical Servs. Fund, 520 U.S. 806 (1997) and California Div. of Labor Standards Enforcement v. Dillingham Constr., N.A., Inc., 519 U.S. 316 (1997). Before that, the Court decided thirteen ERISA-preemption cases in sixteen years. See New York State Conference of Blue Cross \& Blue Shield Plans v. Travelers Ins. Co., 514 U.S. 645 (1995); John Hancock Mut. Life Ins. Co. v. Harris Trust \& Sav. Bank, 510 U.S. 86 (1993); District of Columbia v. Greater Washington Bd. of Trade, 506 U.S. 125 (1992); Ingersoll-Rand Co. v. McClendon, 498 U.S. 133 (1990); FMC Corp. v. Holliday, 498 U.S. 52 (1990); Massachusetts v. Morash, 490 U.S. 107 (1989); Mackey v. Lanier Collection Agency \& Serv., Inc., 486 U.S. 825 (1988); Fort Halifax Packing Co. v. Coyne, 482 U.S. 1 (1987); Metro. Life Ins. Co. v. Taylor, 481 U.S. 58 (1987); Pilot Life Ins. Co. v. Dedeaux, 481 U.S. 41 (1987); Metro. Life Ins. Co. v. Massachusetts, 471 U.S. 724 (1985); Shaw v. Delta Air Lines, Inc., 463 U.S. 85 (1983); Alessi v. Raybestos-Manhattan, Inc., 451 U.S. 504 (1981). The frequency with which the issue presented itself to the Court prompted Justice John Paul Stevens to observe that the issue had also generated an avalanche of litigation in the lower courts. See District of Columbia v. Greater Washington Bd. of Trade, 506 U.S. 125, 135 n.3 (1992) (Stevens, J., dissenting) (observing that in 1992, a LEXIS search uncovered more than 2,800 opinions on ERISA preemption).

218. 29 U.S.C. $\S 1055$ (2006). The objective of $\S 1055$ is to provide "a stream of income to surviving spouses.” Boggs, 520 U.S. at 843. A qualified joint-andsurvivor annuity is an annuity payable for the joint lives of two spouses that 
useless if states allowed "a predeceasing spouse's heirs and legatees to have a community property interest in the survivor's annuity.”219 Additionally, the Court found that "[t]estamentary transfers could reduce a surviving spouse's guaranteed annuity below the minimum set by ERISA," which is $50 \%$ of the annuity that the plan participant would have received for the duration of his and his wife's life. ${ }^{220}$ The Court deemed this conflict to be a "direct clash between state law and ... ERISA.” Hence, state law could not stand. ${ }^{221}$ Allowing Dorothy's testamentary transfer would thwart the intent of ERISA's survivor's annuity and take away Sandra's right to the annuity that she was entitled to receive as Mr. Boggs's surviving spouse. ${ }^{222}$ This is not something that ERISA allows states to do through their communityproperty or testamentary laws. ${ }^{223}$

Dorothy's testamentary transfer also violated ERISA's prohibition on the assignment or alienation of plan benefits intended for plan participants and their beneficiaries. ${ }^{224}$ Under ERISA, beneficiaries of a plan participant are a surviving spouse, a living former spouse, a child, or another dependent—as long as one or more of these persons are designated as a beneficiary in the QDRO. ${ }^{225}$ Dorothy's will did not constitute a QDRO, and so her sons could not be considered beneficiaries. ${ }^{226}$ Dorothy's interest in Mr. Boggs's undistributed plan benefits terminated when she died. ${ }^{227}$ On the other hand, Sandra's interest in those same benefits existed by virtue of ERISA's qualified-joint-survivor-annuity provision. ${ }^{228}$ This meant that Mr. Boggs's sons were not entitled to any of his retirement benefits upon his death because they were not participants in the

terminates when the survivor dies. 29 U.S.C. § 1055(d)(1). An alternate payee who is a former spouse has to have been "married to the participant throughout the oneyear period ending on the earlier of the participant's death or annuity starting date." $\S 1055(f)(1)$.

219. 520 U.S. at 843.

220. Id. at 844 .

221. Id.

222. Id.

223. Id.

224. Id. at 851.

225. Id. at 847 (citing 29 U.S.C. § 1056(d)(3)(K) (2006)).

226. Id. at 848.

227. See id. at 843-44.

228. See id. at 841-44. 
retirement plan nor were they beneficiaries as defined by the statute. $^{229}$

In deciding this case in Sandra's favor, the Court addressed the contention that when state domestic-relations law collides with federal law, preemption should not be presumed simply because domestic-relations law has historically been the domain of the states. $^{230}$ The Court held that community-property laws that conflicted with ERISA had to be preempted in order to ensure the implementation of the federal statutory scheme, particularly the goal of ensuring that retirement funds remained untouched until retirement. $^{231}$

The combination of ERISA's preemptive sweep and its spendthrift provision created a dilemma for state domestic-relations courts. $^{232}$ Because pension benefits could not be assigned or alienated, ${ }^{233}$ and because ERISA preempted all state laws relating to employee-benefit plans, ${ }^{234}$ some courts held that a party's retirement benefits could not be touched, even if that party owed family-support obligations such as alimony, separate maintenance, or child support. $^{235}$ Those courts also held that pension benefits could not be

229. See id. at $851-54$.

230. Id. at 840, 851-53 (citing Hisquierdo v. Hisquierdo, 439 U.S. 572, 581-90 (1979)). “"The whole subject of the domestic relations of husband and wife, parent and child, belongs to the laws of the States and not to the laws of the United States.'” Id. at 848 (quoting In re Burrus, 136 U.S. 586, 593-94 (1890)).

231. Id. at 851-54. "'The anti-alienation provision . . . bespeak[s] a pension law protective policy of special intensity: Retirement funds shall remain inviolate until retirement.'” Id. at 851 (quoting LANGBEIN \& WOLK, supra note 113, at 547). This did not mark the first time that the Court preempted state community-property laws. See, e.g., Mansell v. Mansell, 490 U.S. 581 (1989); Ridgway v. Ridgway, 454 U.S. 46 (1981); McCarty v. McCarty, 453 U.S. 210 (1981); Hisquierdo v. Hisquierdo, 439 U.S. 572 (1979); Free v. Bland, 369 U.S. 663 (1962); Wissner v. Wissner, 338 U.S. 655 (1950); McCune v. Essig, 199 U.S. 382 (1905).

232. S. REP. No. 98-575, at 8-20 (1984), reprinted in 1984 U.S.C.C.A.N. 2547, 2564-66.

233. 29 U.S.C. § 1056(d)(1) (2006).

234. 29 U.S.C. § 1144(a).

235. See, e.g., Monsanto Co. v. Ford, 534 F. Supp. 51, 54 (E.D. Mo. 1981) (holding that divorce-related garnishments or attachments for family-support obligations would violate ERISA's spendthrift clause); Francis v. United Techs. Corp., 458 F. Supp. 84, 86 (N.D. Cal. 1978) (stating that Congress intended ERISA to prevent the voluntary or involuntary assignment or alienation of benefits, with no exception for divorce proceedings); Gen. Motors Corp. v. Townsend, 468 F. Supp. 
divided in connection with a divorce, even if part of those benefits plainly constituted marital or community property under state domestic-relations law. ${ }^{236}$ Other courts reached the opposite conclusion, and held that ERISA did not preempt state domesticrelations law that allowed the attachment of pension benefits to satisfy family-support obligations. They also held that state courts could still use community-property law to award a divorced spouse her marital share of her ex-spouse's retirement benefits. ${ }^{237}$ Adding to

466, 470 (E.D. Mich. 1976) (holding that ERISA forbids the garnishment of a plan participant's retirement benefits to satisfy a judgment obtained in a divorce); Kerbow v. Kerbow, 421 F. Supp. 1253, 1260 (N.D. Tex. 1976) “Congress intended [ERISA] to supersede any and all state laws regulating employee benefit plans.” Id.

236. See cases cited supra note 235.

237. See, e.g., Sav. \& Profit Sharing Fund of Sears Emps. v. Gago, 717 F.2d 1038, 1041-45 (7th Cir. 1983) (holding that ERISA preemption is inapplicable in divorce proceedings), superseded by statute, Retirement Equity Act of 1984, Pub. L. No. 98-397, 98 Stat. 1426; Operating Eng'rs Local No. 428 Pension Trust Fund v. Zamborsky, 650 F.2d 196, 198-202 (9th Cir. 1981) (holding that an implied exception exists to ERISA's anti-alienation provision that allows a garnishment by an ex-spouse for the purpose of satisfying a court-ordered spousal-maintenance obligation), superseded by statute, Retirement Equity Act of 1984, Pub. L. No. 98397, 98 Stat. 1426; Carpenters Pension Trust for S. Cal. v. Kronschnabel, 632 F.2d 745, 748 (9th Cir. 1980) (holding that the Supreme Court's dismissal of the previous case for want of a substantial federal question constituted a decision on the merits that ERISA did not prevent application of California property law); Stone v. Stone, 632 F.2d 740, 742 (9th Cir. 1980) (stating that ERISA does not preempt a court order requiring a pension plan to pay community-property share of benefits to former spouse); Cody v. Riecker, 594 F.2d 314, 315-17 (2d Cir. 1979) (holding that ERISA does not prohibit garnishments in aid of state-court orders requiring family-support payments); Am. Tel. \& Tel. Co. v. Merry, 592 F.2d 118, 124 (2d Cir. 1979) (stating that state garnishment of a spouse's pension income to enforce alimony and support orders is not preempted); Eichelberger $\mathrm{v}$. Eichelberger, 584 F. Supp. 899, 900-01 (S.D. Tex. 1984) (holding that ERISA does not preempt Texas community-property law), superseded by statute, Retirement Equity Act of 1984, Pub. L. No. 98-397, 98 Stat. 1426; Cent. States v. Parr, 480 F. Supp. 924, 925 (E.D. Mich. 1979) (holding that pension benefits can be garnished to satisfy temporary alimony obligations); Senco of Florida, Inc. v. Clark, 473 F. Supp. 902, 908 (M.D. Fla. 1979) (holding that garnishment of an employee's pension benefits for child support or alimony is not prohibited under federal law); Cartledge v. Miller, 457 F. Supp. 1146, 1156 (S.D.N.Y. 1978) (holding that ERISA does not preempt valid spousal or support claims); In re Marriage of Campa, 152 Cal. Rptr. 362, 367-68 (Cal. Ct. App. 1979) (stating that it does not violate ERISA to make a pension plan a party to a marriage-dissolution proceeding and order it to send one-half of a monthly benefit check to the participant and one-half to the participant's former spouse), appeal dismissed for want of a substantial federal 
the confusion, the IRS ruled that ERISA's spendthrift clause did not prohibit a pension-plan administrator from honoring a state-court order requiring the distribution of a plan participant's benefits if the participant started receiving benefits and if the court ordered the distribution to fulfill the participant's alimony or child-support obligations. ${ }^{238}$ The IRS did not express an opinion on situations in which the participant had not started receiving benefits. ${ }^{239}$

For women who did not have their own pensions, this judicial uncertainty caused a particular hardship. ${ }^{240}$ When Congress passed ERISA in 1974, it did not clearly state whether a spouse would have an interest in her spouse's pension benefits in the event of the death of, or a divorce from, that spouse. ${ }^{241}$ Because of this ambiguity, a wife could be deprived of her marital- or community-property share of her husband's pension benefits if he died or if the couple divorced. ${ }^{242}$

Before ERISA, pensions were viewed as contracts between employers and employees and were primarily subject to regulation under state law. ${ }^{243}$ "ERISA federalized pension law [and established national] rules governing the creation, administration, and

question sub nom. Carpenters Pension Trust Fund for N. Cal. v. Campa, 444 U.S. 1028 (1980), superseded by statute, Retirement Equity Act of 1984, Pub. L. No. 98-397, 98 Stat. 1426; W. Electric Co. v. Traphagen, 400 A.2d 66, 71 (N.J. Super. Ct. App. Div. 1979); Biles v. Biles, 394 A.2d 153, 157 (N.J. Super. Ct. Ch. Div. 1978); Cogollos v. Cogollos, 402 N.Y.S.2d 929, 929-30 (N.Y. Sup. Ct. 1978); Wanamaker v. Wanamaker, 401 N.Y.S.2d 702, 706 (N.Y. Fam. Ct. 1978).

238. Rev. Rul. $80-27,1980-1$ C.B. 85.

239. S. REP. NO. 98-575, at 19 (1984), reprinted in 1984 U.S.C.C.A.N. 2547, 2565.

240. See Jaffke, supra note 3, at 264. See generally S. REP. No. 98-575, at 1, reprinted in 1984 U.S.C.C.A.N. at 2547.

241. Ablamis v. Roper, 937 F.2d 1450, 1453 (9th Cir. 1991) (citing 29 U.S.C. § 1001(a) (2006)).

242. Id. (citing Pension Equity for Women: Hearings on H.R. 2100 Before the Subcomm. on Labor-Mgmt. Relations of the Comm. on Educ. \& Labor, 98th Cong. 26 (1983) (statement of Hon. Geraldine Ferraro)).

243. See In re Schenectady Ry. Co., 93 F. Supp. 67, 70 (N.D.N.Y. 1950) (stating that pensions are part of the terms of the contract); Cantor v. Berkshire Life Ins. Co., 171 N.E.2d 518, 521 (Ohio 1960) (stating that pension arrangements give rise to contractual rights enforceable by the employee); Zimmerman v. Brennan, 202 N.W.2d 923, 926 (Wis. 1973) (stating that retirement plans are treated like a contract); T.P. Gallanis, ERISA and the Law of Succession, 65 OHIO ST. L.J. 185, 185-86 (2004). 
termination of most pension plans." ${ }^{244}$ In short, ERISA was a congressional tour de force. Not quite a decade after it became effective, however, Congress had to act again to address ERISA's unintended consequences - namely, undercutting the marital and succession rights of widows and widowers to their spouses' pension benefits. $^{245}$

\section{THE REA, THE SURVIVOR ANNUITY, AND THE BIRTH OF THE QDRO}

\section{A. The Survivor Annuity}

President Ronald Reagan signed the REA into law on August 23, 1984. ${ }^{246}$ Congress passed the REA primarily to safeguard the financial security of widows, widowers, and divorcees. ${ }^{247}$ The REA "afforded protection to widows (and widowers) by requiring pension plans to provide automatic survivor benefits." 248 Once a plan participant earns a nonforfeitable right to any part of his or her accrued pension benefits, the participant's spouse will receive a survivor's annuity if the participant predeceases the spouse. ${ }^{249}$ In such cases, the plan administrator must pay the surviving spouse between $50 \%$ and $100 \%$ of the participant's benefits. ${ }^{250}$ This is called a qualified joint-and-survivor annuity. ${ }^{251}$ If the plan participant dies

244. Gallanis, supra note 243, at 186.

245. See Retirement Equity Act 1984, Pub. L. No. 98-397, 1984 U.S.C.C.A.N. (98 Stat. 1426) 2547, 2564-66.

246. Statement on Signing H.R. 4280 into Law, 20 WEEKLy COMP. PRES. DoC. 1161 (Sept. 3, 1984).

247. See Ablamis, 937 F.2d at 1453 (citing Mackey v. Lanier Collections Agency \& Serv., 486 U.S. 825, 838 (1988) (stating that the primary focus of the QDRO exception to ERISA's anti-alienation clause is to allow spouses to enforce domestic-support orders); Heisler v. Jeep Corp.-UAW Ret. Income Plan, 807 F.2d 505, 509 (6th Cir. 1986) (stating that the REA sought to rectify certain inequities by providing automatic survivor benefits to spouses of vested plan participants); Gabrielson v. Montgomery Ward \& Co., 785 F.2d 762, 765 (9th Cir. 1986) (stating that Congress amended 29 U.S.C. § 1055 to enlarge the rights of surviving spouses to receive benefits).

248. Ablamis, 937 F.2d at 1453 (citing Pension Equity for Women: Hearings on H.R. 2100 Before the Subcomm. on Labor-Mgmt. Relations of the Comm. on Edu. \& Labor, 98th Cong. 26-27 (1983)) Although Congress primarily concerned itself with widows, the REA's survivorship clauses also benefits widowers also. Id.

249. Id. at 1453 n.6 (citing 29 U.S.C. § 1055(d)(1) (2006)).

250. 29 U.S.C. § 1055(d)(1)(A).

251. 29 U.S.C. $\S 1055(d)(1)$. 
before he or she starts receiving pension benefits, then the surviving spouse may still receive benefits in the form of a qualified preretirement survivor annuity. ${ }^{252}$ In such cases, the annuity must be at least equal to the payments that would have been made under a qualified joint-and-survivor annuity. ${ }^{253}$

The survivor annuity is mandatory and cannot be waived unless a writing is executed by the plan participant and his spouse and the writing is either notarized or the signing is witnessed by a plan representative. ${ }^{254}$ Once the surviving spouse dies, the annuity terminates. ${ }^{255}$ The surviving spouse cannot bequeath the annuity benefits. ${ }^{256}$

\section{B. The Birth of the QDRO}

Prior to the REA, federal and state courts were split on the question of whether state-court orders issued in domestic-relations proceedings could affect the distribution of pension benefits governed by ERISA. Some courts held that ERISA barred such distributions, and others held that it did not. ${ }^{257}$ Responding to this uncertainty and “"taking into account changes in work patterns, the status of marriage as an economic partnership, and the substantial contribution to that partnership [made by] spouses who work ... in the home and outside the home,"' the REA created an exception to ERISA's spendthrift provision. ${ }^{258}$ The exception specifically allows state-court-ordered assignments of plan benefits to former spouses and dependents. ${ }^{259}$ This exception to ERISA's spendthrift clause is called a QDRO. ${ }^{260}$

252. 29 U.S.C. § 1055(e). An alternate payee who is a former spouse must have been married to the participant throughout the one-year period ending on the earlier of the participant's death or annuity starting date. § 1055(f)(1).

253. 29 U.S.C. $\S 1055(\mathrm{e})(1)(\mathrm{A})$.

254. 29 U.S.C. § 1055(c)(2).

255. Ablamis v. Roper, 937 F.2d 1450, 1454 (9th Cir. 1991).

256. Id.; see also Boggs v. Boggs, 520 U.S. 833, 841-45 (1997).

257. Trs. of the Dirs. Guild of Am.-Producer Pension Benefits Plans v. Tise, 234 F.3d 415, 419 (9th Cir. 2000); see supra notes 236-38.

258. Tise, 234 F.3d at 419 (citing S. REP. No. 98-575, at 1 (1984), reprinted in 1984 U.S.C.C.A.N. (98 Stat. 1426) 2547, 2547; Stewart v. Thorpe Holding Co., 207 F.3d 1143, 1149 (9th Cir. 2000); Ablamis, 937 F.2d at 1452-53).

259. Id.

260. 29 U.S.C. § 1056(d)(3) (2006). 
A QDRO is a particular type of domestic-relations order, which is an order "made pursuant to State domestic relations law [or] community property law [relating to] the provision of child support, alimony, or marital property rights to a spouse, former spouse, child, or other dependent of a [pension-plan] participant." ${ }^{261}$ A QDRO is a domestic-relations order that "creates or recognizes the existence of an alternate payee's right to, or assigns to an alternate payee the right to, receive all or [part] of the benefits payable" to a participant in an ERISA pension plan. ${ }^{262}$ The order cannot "require a plan to provide any type or form of benefit or . . . option not otherwise provided under the plan;" it cannot require the plan "to provide increased benefits;" and it cannot require the plan to pay benefits to an alternate payee if those benefits are supposed to be paid to another alternative payee under the terms of previously entered QDRO. ${ }^{263}$ Finally, the order must clearly specify the following: (1) the name and address of the participant; (2) the name and address of the alternate payee; (3) the amount or percentage of the participant's benefits to be paid by the plan to the alternate payee or how the amount or percentage will be calculated; (4) the number of payments or payment periods; and (5) each plan covered by the order. ${ }^{264}$

The QDRO is not only an exception to ERISA's spendthrift clause; it is also an exception to ERISA's preemption of state domestic-relations law. ${ }^{265}$ However, this does not mean that all domestic-relations orders are exempt from these two provisions; only domestic-relations orders that are QDROs as defined by the REA are exempted from ERISA's spendthrift and preemption clauses. ${ }^{266}$ State domestic-relations orders can create enforceable interests in a person's benefits under an ERISA-qualified plan, provided that those

261. 29 U.S.C. § 1056(d)(3)(B)(ii).

262. 29 U.S.C. § 1056(d)(3)(B)(i)(I). An ““alternate payee’ is a spouse, former spouse, child, or other dependent of a participant who is recognized by a domesticrelations order as having a right to receive all, or a portion of, the benefits payable under a plan with respect to such participant.” 29 U.S.C. § 1056(d)(3)(K).

263. 29 U.S.C. § 1056(d)(3)(D)(i)-(iii).

264. 29 U.S.C. § 1056(d)(3)(C)(i)-(iv).

265. Trs. of the Dirs. Guild of Am.-Producer Pension Benefits Plans v. Tise, 234 F.3d 415, 419 (9th Cir. 2000) (citing 29 U.S.C. § 1144(b)(7)).

266. 29 U.S.C. § 1056(d)(3)(A). 
orders comply with the REA's QDRO requirements. ${ }^{267}$ All other domestic-relations orders are expressly subject to the spendthrift and preemption clauses. $^{268}$

The primary responsibility for determining whether a domesticrelations order is a QDRO rests with the ERISA plan to which it is directed. ${ }^{269}$ Plans typically have a person designated as the plan administrator who undertakes this responsibility. ${ }^{270}$ Plan administrators need not be, and in most cases are not, lawyers. ${ }^{271}$ Once a plan administrator receives a domestic-relations order to determine if it is a QDRO, ERISA does not allow him to "look beneath the surface" of that order or to second guess state judges' decisions under state law. ${ }^{272}$

After obtaining a domestic-relations order in a state-court proceeding, an alternate payee must present the order to the plan administrator so that the administrator can determine if it is a QDRO. ${ }^{273}$ Once the administrator receives the order, he must "promptly notify the participant and each alternate payee of the receipt of [the] order and the plan's procedures for determining the qualified status" of the order. ${ }^{274}$ Additionally, within a reasonable time, the plan administrator must determine whether it is a QDRO

267. S. REP. NO. 98-575, at 19 (1984), reprinted in 1984 U.S.C.C.A.N. 2547, 2565 “[ERISA's] spendthrift rules should be clarified by creating a limited exception that permits benefits under a pension ... plan to be divided under certain circumstances. ... [C]hanges to the ERISA preemption provision are necessary to ensure that only those orders that are excepted from the spendthrift provisions are not preempted by ERISA". Id.

268. Id.

269. 29 U.S.C. § 1056(d)(3)(G)(i). When the plan administrator receives a domestic-relations order, he must do the following:

(I) [P]romptly notify the participant and each alternate payee of the receipt of such order and the plan's procedures for determining the qualified status of domestic relations orders, and

(II) within a reasonable period after receiving such order, [he] shall determine whether such order is a qualified domestic relations order and notify the participant and each alternate payee of such determination.

Id.

270. 29 U.S.C. § 1002(16)(A).

271. Blue v. UAL Corp., 160 F.3d 383, 386 (7th Cir. 1998).

272. Id. at 385-86.

273. 29 U.S.C. § 1056(d)(3)(G)(i)(II).

274. 29 U.S.C. § 1056(d)(3)(G)(i)(I). 
and notify the participant and each alternate payee of that determination. ${ }^{275}$ Thus, "whether an alternate payee has an interest in a participant's pension plan is a matter decided [in] a state court proceeding [under that] state's domestic relations law."276 "Whether [that] state court order meets the statutory requirements to be a QDRO and . . . is enforceable against the pension plan, [however,] is a matter to be determined in the first instance by the plan administrator, and if necessary, by a court of competent jurisdiction."277

While the plan administrator is determining whether a domesticrelations order is a QDRO, he must "segregate the benefits that would be due to the alternate payee under the terms of the [order] during the first 18 months that those benefits would be payable if the [order] is ultimately deemed a QDRO.”278 If the order is determined to be a QDRO within the benefit-segregation period, then the plan administrator must pay the segregated benefits, including interest, to the alternate payee. ${ }^{279}$ If, however, during the benefit-segregation period the order is determined not to be a QDRO, then the plan administrator must pay the segregated benefits, including interest, to the person who would otherwise have been entitled to the benefits if there were no QDRO. ${ }^{280}$ If the plan administrator thereafter determines that a domestic-relations order is a QDRO, then the plan must start paying benefits to the alternate payee. The plan, however, cannot make payments retroactively. ${ }^{281}$

Underlying this benefits-segregation period is the assumption that benefits might be payable during the period that the plan administrator is determining if the domestic-relations order is a QDRO. ${ }^{282}$ Congress knew that further litigation in state court might take place during the QDRO-determination period, which would provide an alternate payee the opportunity to make the changes necessary to get the original domestic-relations order qualified as a

275. 29 U.S.C. § 1056(d)(3)(G)(i)(II).

276. Trs. of the Dirs. Guild of Am.-Producer Pension Benefits Plans v. Tise, 234

F.3d 415, 421 (9th Cir. 2000).

277. Id. (citing 29 U.S.C. § 1056(d)(3)(H)(i)).

278. Id. (citing 29 U.S.C. § 1056(d)(3)(H)(v)).

279. 29 U.S.C. § 1056(d)(3)(H)(ii).

280. 29 U.S.C. § 1056(d)(3)(H)(iii).

281. Tise, 234 F.3d at 422 (citing 29 U.S.C. § 1056 (d)(3)(H)(iv)).

282. Id. 
QDRO. ${ }^{283}$ Congress did not intend, however, that plan administrators take eighteen months to determine if a domestic-relations order qualifies as a QDRO. ${ }^{284}$ The point of the eighteen-month period is to allow enough time to cure any defects in the order that a person seeks to have qualified as a QDRO. ${ }^{285}$ This is reflected in the language of the statute, ${ }^{286}$ that says that an alternate payee may present the plan administrator with modifications to the original domestic-relations order within the eighteen-month benefit-segregation period. ${ }^{287}$ If the plan administrator determines before the end of the segregation period that a modified order is a QDRO, then the alternate payee's entitlement to the benefits is fully protected. ${ }^{288}$

This process seems straight-forward enough: (1) draft a domesticrelations order that includes what the REA says it must include to be qualified as a QDRO; (2) present the order to the plan administrator; and (3) wait to hear whether the order qualifies as a QDRO. If it does not qualify, then the attorney must do the following: make whatever changes are necessary to satisfy the plan administrator, submit the order anew to have it qualified as a QDRO, and take satisfaction in knowing that the attorney served his or her client well by securing the client's interest in his or her ex-spouse's pension benefits. As with so many things, however, there is quite a bit of distance between theory and reality. The journey from domestic-relations order to QDRO can be treacherous. This Article will now turn to helping those involved in this journey avoid the most common traps for the unwary.

283. Id.

284. Id. "[W]ithin a reasonable period after receipt of [the] order, the plan administrator [must] determine whether [the] order is a qualified domestic relations order . . . .” 29 U.S.C. $\S 1056(d)(3)(G)(i)(I I)$. The Department of Labor's position is that the eighteen-month benefit-segregation period "is not the measure of the reasonable period for determining the qualified status of an order and in most cases would be an unreasonably long period of time to take to review an order.” QDROs: The Division of Retirement Benefits Through Qualified Domestic Relations Orders, supra note 9.

285. QDROs: The Division of Retirement Benefits Through Qualified Domestic Relations Orders, supra note 9.

286. Tise, 234 F.3d at 422.

287. Id. (citing 29 U.S.C. § 1056(d)(3)(H)(ii)).

288. Id. (citing 29 U.S.C. § 1056(d)(3)(H)(ii)). 


\section{PlANS COVERED By ERISA}

Before preparing a domestic-relations order for qualification as a QDRO, the drafter must have some understanding of the type of plan that he attempting to divide. ERISA governs most, but not all, pension plans in the United States. ${ }^{289}$ Most of these plans are definedbenefit plans, ${ }^{290}$ defined-contribution plans, ${ }^{291}$ or cash-balance pension plans. $^{292}$

\section{A. Defined-Benefit Plans}

In a defined-benefit pension plan, the employer promises to provide the employee a fixed benefit upon retirement-usually related to the employee's service, pay, or some combination of the two." 293 "Retirement benefits depend on a calculation of average earnings either under a final-average or career-average formula . . . .294 The final-average formula bases the level of benefits on "earnings averaged, for example, over the last three years of employment or over the three consecutive years in a ten year period immediately prior to retirement in which earnings are the highest.”295

289. Dean, supra note 9, at 652-55; see supra notes 138-43.

290. A defined-benefit plan means "a pension plan other than an individual account plan.” 29 U.S.C. § 1002(35).

291. A defined-contribution plan means "a pension plan [that] provides for an individual account for each participant and for benefits based solely upon the amount contributed to the participant's account, and any income, expenses, gains and losses, and any forfeitures of accounts of other participants which may be allocated to such participant's account.” 29 U.S.C. § 1002(34).

292. 29 U.S.C. § 1054(b)(5)(A)-(G). "In 2006, Congress enacted the Pension Protection Act ('PPA'), which amended the Employee Retirement Income Security Act of 1974 ('ERISA') to specifically allow for cash balance defined benefit plans.” Hirt v. Equitable Ret. Plan for Emps., Managers \& Agents, 533 F.3d 102, 104 (2d Cir. 2008) (citing Pension Protection Act of 2006, Pub. L. No. 109-280, § 701(a)(1), 120 Stat. 780, 981 (codified as amended at $\S 1054(b)(5)(A)-(G))$ ). "The amendment, however, applies only to periods beginning on or after June 29, 2005.” Id. (citing Pension Protection Act of 2006, Pub. L. No. 109-280, § 701(e)(1), 120 Stat. 780, 991); see also T. Leigh Anenson \& Karen Eilers Lahey, The Crisis in Corporate America: Private Pension Liability and Proposals for Reform, 9 U. PA. J. LAB. \& EMP. L. 495, 502 (2007).

293. Anenson \& Lahey, supra note 292, at 500.

294. Id.

295. Id. (citing Everett T. Allen, Jr., Et. Al., Pension Planning: Pension, Profit-Sharing, AND Other DefERred Compensation Plans 229-34 (Michele Janicek ed., 9th ed. 2003)). 
The career-average formula "bases benefits on earnings averaged over the entire career of employment." 296 The employee is paid for the remainder of his or her life, and subsidized early retirement benefits are usually included in the plan. ${ }^{297}$

The employee may or may not contribute to the plan, but any contributions are usually fixed. ${ }^{298}$ The employer's contributions, however, are not fixed. If the plan's investments perform below expectations, then the employer will have to pay more into the fund in order to fulfill its obligation to pay the retirement benefits that are promised in the plan. ${ }^{299}$ On the other hand, if the plan's investments perform better than expected, then the employer may not have to contribute as much and instead may rely on the fund's investment earnings to pay promised benefits. ${ }^{300}$ "The employer bears the risk that the employee or [his] spouse will live long enough to [receive] all the benefits paid into the pension plan" because if there are insufficient funds in the plan to pay for those benefits, then the employer has to make up the difference. ${ }^{301}$ " [T] $[$ he employer's cost[s also] include[] the amount necessary to provide the benefit as well as administrative and actuarial expenses." ${ }^{302}$

“[D]efined benefit pensions are insured against default by the PBGC, [and employers] pay insurance premiums per employee for each employee participating in the pension [plan].”303 Employers "also pay variable rate premiums should their funding ratios fall below [a] statutory average."304 These plans can be very expensive for employers because the formula for determining the promised benefits can become backloaded due to the high salaries of long-time employees during the last three to five years of employment. ${ }^{305}$

296. Id.

297. Id.

298. Montgomery v. United States, 18 F.3d 500, 501 (7th Cir. 1994).

299. Id.

300. Id. at 501-02.

301. Dean, supra note 9, at 654 (citing Kathleen H. Czarney, Note, The Future of Americans' Pensions: Revamping Pension Plan Asset Allocation To Combat the Pension Benefit Guaranty Corporation's Deficit, 51 CLEV. ST. L. REV. 153, 166 (2004)).

302. Anenson \& Lahey, supra note 292, at 500.

303. Id.

304. Id. at 500-01; see also 29 U.S.C. § 1082(a)(1) (2006).

305. Angela Boothe Noel, The Future of Cash Balance Plans: Inherently Illegal or a Viable Pension Option?, 56 ALA. L. REV. 899, 899-900 (2005). 
Defined-benefit plans used to be the predominant type of pension plan in the United States, but now fewer than $20 \%$ of private-sector employees are covered by defined-benefit plans. ${ }^{306}$

\section{B. Defined-Contribution Plans}

Defined-contribution plans provide participants with individual accounts that are funded by contributions from the participants, employers, or both. ${ }^{307}$ When the participant retires, he or she may liquidate the account or draw periodic payments from it. ${ }^{308}$ Contributions to the account are invested, which results in a balance that consists of the contributions, plus investment gains, minus expenses and investment losses. ${ }^{309}$ The "benefit is not 'defined[]' [because] it depends on the investment performance of the retirement fund." 310 Employees assume the investment risk and the risk that they may outlive the amount in their accounts at retirement. ${ }^{311}$ Two popular defined-contribution plans are $401(\mathrm{k})^{312}$ and 403(b) ${ }^{313}$ plans. The defined-contribution plan is the most popular private-sector retirement plan because employers prefer that the risk of funding retirement be borne by employees. ${ }^{314}$ These plans are not insured by the PBGC. ${ }^{315}$

306. Dean, supra note 9, at 653 (citing Matthew Venhorst, Note, Helping Individual Investors Do What They Know Is Right: The Save More for Retirement Act of 2005, 13 ConN. INs. L.J. 113, 115 (2006-2007)) (stating that $62 \%$ of all workers had defined-benefit plans in the 1970s; that number dropped to $13 \%$ by 1997).

307. 26 U.S.C. § 414(i).

308. Dean, supra note 9, at 654 (citing Edward A. Zelinsky, The Defined Contribution Paradigm, 114 YALE L.J. 451, 463-64 (2004) (stating that definedcontribution plans normally pay participants in a lump sum upon their retirement, and then it is up to them to invest the funds or purchase an annuity contract)).

309. 26 U.S.C. § 414(i).

310. Montgomery v. United States, 18 F.3d 500, 501 (7th Cir. 1994).

311. See Anenson \& Lahey, supra note 292, at 501.

312. 26 U.S.C. $\S 401(\mathrm{k})$.

313. 26 U.S.C. $\S$ 403(b). Section 403(b) plans are essentially 401(k) plans for persons who work for tax-exempt organizations or public schools. See id.

314. Dean, supra note 9, at 654-55.

315. General FAQs About PBGC, Pension Benefit Guarantee Corporation, http://www.pbgc.gov/about/faq/pg/general-faqs-about-pbgc.html (last visited Jan. 12, 2012). 
“[In] 2002, employees and their employers contributed over \$84 billion to defined contribution pension plans . . . bringing the amount held in such plans on behalf of many of America's [workers] to nearly $\$ 2$ trillion .....316 This amount exceeded the assets of defined-benefit pension plans by over $\$ 200$ million. $^{317}$ Over one-half of "private pension plan assets are held in [defined-contribution] plans." 318 By way of comparison, in 2002, contributions to definedcontribution plans and defined-benefit plans were approximately $\$ 80$ billion and $\$ 39$ billion, respectively. ${ }^{319}$

\section{Cash-Balance Pension Plans}

The cash-balance plan is a defined-benefit plan with many features of a defined-contribution plan. ${ }^{320}$ The employee has an account that consists of "[his] contributions at a specified rate of interest." 321 It is a defined-benefit plan:

[B]ecause the employer bears the investment risk and guarantees a particular benefit at retirement. If the account earns more interest on the funds [than is necessary to pay benefits] the employer keeps the excess. If the account earns less interest, [then] the employee is still assured an amount at the specified interest rate. Cash balance plans provide [fairly] uniform increases in benefits during [a worker's] employment and do not have the [substantial increase] in benefits embodied in the final average formulas of . . . traditional defined benefit plans. Rather than offering deferred annuity payments based on a salary

316. Paul J. Donahue, Plan Sponsor Fiduciary Duty for the Selection of Options in Participant-Directed Defined Contribution Plans and the Choice Between Stable Value and Money Market, 39 AKRON L. REV. 9 , 9 (2006).

317. Id.

318. Id. at 11.

319. Id.

320. Anenson \& Lahey, supra note 292, at 502 (citing Edward A. Zelinsky, The Cash Balance Controversy, 19 VA. TAx REv. 683, 715-16 (2000)).

321. Id.; see Treas. Reg. § 1.401(a)(4)-8(c)(3)(i) (as amended in 2001); I.R.S. Notice 96-8, 1996-1 C.B. 359. 
and service formula, cash balance plans typically distribute retirement benefits in one lump sum. ${ }^{322}$

The plans are insured by the PBGC. ${ }^{323}$ Cash-balance plans have become quite popular, particularly among employers with cashstrapped defined-benefit plans, and thousands of employers have converted their defined-benefit plans into cash-balance plans. ${ }^{324}$ Once

322. Anenson \& Lahey, supra note 292, at 502 (citing Zelinsky, supra note 320, at 693-94) (citing Everett T. Allen, JR., ET. Al., Pension Planning: Pension, Profit-Sharing, AND Other Deferred Compensation 345-46 (9th ed. 2003); Patrick J. Purcell, Cong. Research Serv., RL30496, Pension Issues: LumpSuM DisTRIBUTIONS AND RETIREMENT INCOME SECURITY 6 (2003)).

323. General FAQs About PBGC, supra note 316.

324. Fike, supra note 9, at 236-37. This conversion process has proved quite controversial. CARRAD, supra note 9, at 17-18; Reiss, supra note 27, at 8 . Under a traditional defined-benefit plan, a participant's benefits are typically based on his final average earnings when his pay is usually at an apex. SHULMAN, supra note 16, $\S 14.01$. For example, a plan may base a participant's pension on the average salary she earns between the ages of sixty and sixty-five. Id. If the employee retires with forty years of service at age sixty-five, then her final average salary will be multiplied by a factor incorporating all forty years of her service. Id. Thus, as the employee continues to work year after year, her pension benefits will increase substantially because the previous years of employment will push up her final average salary. Id. Under a cash-balance plan, however, the participant receives an annual pension credit for each year's salary, i.e., the contribution to the employee's cash-balance account will be based on a percentage of her salary earned in that particular year. Id. These credits must be valued based on an annuity for the employee beginning at age sixty-five. Cooper v. IBM Pers. Pension Plan, 274 F. Supp. 2d 1010, 1021 (S.D. Ill. 2003); 28 U.S.C. § 1002(23)(A), (24) (2006). For an age-sixty-five annuity, the credits will always be more valuable for a younger worker than an older one. Cooper, 274 F. Supp. 2d at 1021. "[E]ach year, as a cash balance participant ages, the same contribution made for [her] in the previous year declines in value in annuity terms." Id. (citing Zelinsky, supra note 320, at 733 (2000)). Additionally, cash-balance plans "measure accrued benefits in terms of annuities, not in terms of [annual] contributions." Id.

The rate of a participant's benefit accrual decreases as she approaches age sixty-five. Cooper, 274 F. Supp. 2d at 1022. For example, a forty-nine-year-old worker with twenty years of service accrues an age-sixty-five annuity of \$8,093 in the year 2000. Id. at 1021. The next year, she accrues an additional \$622, and by 2010, his additional accrual is $\$ 282$. Id. This forty-nine-year-old's benefit accrual is reduced each year. Id. at 1021-22. Had this employee been a participant in a defined-benefit plan, her pension calculation would not be based on a single year's earnings, but on her average annual earnings during the last years of employment when her earnings are much higher. CARRAD, supra note 9, at 17; SHULMAN, supra note 16, § 14.01. This disadvantages older workers because benefits accrued under 
the domestic-relations practitioner learns what type of plan that he has to divide for his client, the drafting process begins.

\section{COMMON QDRO ERRORS}

\section{A. Lack of an Awareness that QDROs Exist or Are Required}

QDROs came into existence on August 23, 1984, when President Ronald Reagan signed the REA. ${ }^{325}$ Initially, the most common error in the preparation of QDROs was the lack of awareness that QDROs even existed. ${ }^{326}$ The law of marriage and divorce in this country dates

a cash-balance plan will be substantially less than those accumulated under a defined-benefit plan. CARRAD, supra note 9, at 17; SHULMAN, supra note 16, § 14.01 .

In 1999, a group of IBM employees filed a class-action lawsuit in federal district court arguing that IBM's conversion of its defined-benefit pension plan to a cash-balance plan violated ERISA's prohibition on age discrimination. Cooper, 274 F. Supp. 2d at 1010-14. The court agreed and ruled that IBM's conversion violated ERISA. Id. at 1010. The United States Court of Appeals for the Seventh Circuit reversed, holding that IBM's cash-balance plan did not unlawfully discriminate on the basis of age. Cooper v. IBM Pers. Pension Plan, 457 F.3d 636, 637-43 (7th Cir. 2006). The court agreed with the employees' basic premise that the funding of IBM's cash-balance plan advantaged younger workers while disadvantaging older ones but found the argument insufficient to establish age discrimination because it is inapposite to compare the time value of money with age discrimination. $I d$. at 642. The court stated that it is essential to separate age discrimination from characteristics that may be correlated with age (wages rise with seniority and with age, but distinctions based on wage levels do not discriminate based on age). Id. A plaintiff alleging age discrimination must demonstrate an adverse action because of age, and the court found IBM's plan to be age-neutral. Id.

The Second, Third, Sixth, and Ninth Circuits followed Cooper in cases where employees alleged that cash-balance plans violate ERISA's ban on age discrimination. Hurlic v. S. California Gas Co., 539 F.3d 1024, 1028 (9th Cir. 2008); Hirt v. Equitable Ret. Plan for Emps., Managers, \& Agents, 533 F.3d 102 (2d Cir. 2008); Drutis v. Rand McNally \& Co., 499 F.3d 608, 609 (6th Cir. 2007); Register v. PNC Fin. Servs. Grp., Inc., 477 F.3d 56, 67-74 (3d Cir. 2007). The Fifth Circuit suggested in dicta that it would have joined the Second, Third, Sixth, Seventh, and Ninth Circuits had the employee not abandoned the argument on appeal. Rosenblatt v. United Way of Greater Hous., 607 F.3d 413, 419 (5th Cir. 2010). The Eighth Circuit had the issue before it but did not decide the question because the employees waived the argument on appeal. Sunder v. U.S. Bancorp Pension Plan, 586 F.3d 593, 603 (8th Cir. 2009).

325. 20 WeEkly Comp. Pres. DoC. 1161 (Sept. 3, 1984); 29 U.S.C. § 1056(d)(3) (2006).

326. Simmons \& Watson, supra note 27 , at 3-4. 
back to the establishment of the American colonies; ${ }^{327}$ by comparison, QDROs are of a fairly recent vintage. Thus, it is arguably understandable that fewer than three years after Congress created QDROs, some practitioners might not have been aware of their necessity or importance. ${ }^{328}$ Today, however, no one can reasonably make that claim.

It is not enough to add language to a separation agreement, divorce decree, or property-settlement agreement that states that one spouse is to receive all or some portion of the other spouse's retirement benefits. If that is all that the lawyer does to secure a client's marital- or community-property share of her spouse's retirement benefits, then the lawyer has invited side litigation on the issue of whether the separation agreement, divorce decree, or property-settlement agreement substantially complies with the REA's QDRO requirements. ${ }^{329}$ While courts have liberally construed the

327. Roberto Bell, The History of Divorce in the US, ARTICLE DASHBOARD (Mar. 3, 2012, 7:22 PM), http://www.articledashboard.com/Article/The-HistoryOf-Divorce-In-The-US/971637.

328. In re Williams, 50 F. Supp. 2d 951, 958 n.11 (C.D. Cal. 1999) (stating that by 1987, the REA and QDROs were firmly established law).

329. See, e.g., Metro. Life Ins. Co. v. Wheaton, 42 F.3d 1080, 1081-85 (7th Cir. 1994). The Seventh Circuit held that a divorce decree that failed to explicitly name the plan that the order pertained to and failed to specify how the proceeds were to be divided between alternate payees was nevertheless sufficient to qualify as a QDRO because there was no ambiguity about how to dispense the proceeds of the ERISA plan. Id. In that case, the divorce decree simply referred to the plan at issue as "the life insurance [that] is presently carried through his/her employer." Id. at 1081. In so holding, the court stated the following:

It is asking too much of domestic relations lawyers and judges to expect them to dot every $\mathrm{i}$ and cross every $\mathrm{t}$ in formulating divorce decrees that have ERISA implications. Ideally, every domestic relations lawyer should be conversant with ERISA, but it is unrealistic to expect all of them to be. We do not think Congress meant to ask the impossible, not the literally, but the humanly, impossible, or to make a suit for legal malpractice the sole recourse of an ERISA beneficiary harmed by a lawyer's failure to navigate the treacherous shoals with which the modern state-federal law of Id. at 1085. employee benefits abounds.

The Ninth Circuit came to a similar conclusion when presented with the question of what degree of compliance with the REA will suffice to have a domestic-relations order deemed a QDRO. Stewart v. Thorpe Holding Co. Profit Sharing Plan, 207 F.3d 1143, 1149-55 (9th Cir. 2000). 
criteria by which a domestic-relations order will qualify as a QDRO, ${ }^{330}$ litigating the issue will cost the client time and money.

This can be avoided by making a QDRO checklist for each domestic-relations order. The first four items on the checklist should include: (1) the names and addresses of the participant and the alternate payee; (2) the amount or percentage of the participant's benefits to be paid by the plan to the alternate payee, or how the amount or percentage will be calculated; (3) the number of payments or payment periods; and (4) each plan covered by the order. ${ }^{331}$ Next, confirm that the order does not do any of the following: (1) require the plan to provide benefits that it does not otherwise provide according to its terms; (2) obligate the plan to increase the benefits provided; or (3) eliminate benefits that are designated under a preexisting QDRO. ${ }^{332}$ These requirements exist "to 'spare the plan administrator from litigation-fomenting ambiguities [about] who the beneficiaries . . . are.",333

With all that said, who is responsible to draft the order that will be submitted to the plan administrator for a QDRO determination? ${ }^{334}$ The domestic-relations judge will not draft the order. ${ }^{335}$ Understanding QDROs requires knowledge of the tax and labor portions of ERISA. These areas of law arise infrequently in state court; thus, the judge who signs off on a domestic-relations order may not be familiar with the inner workings of ERISA or the REA.

Similarly, plan administrators will not draft QDROs. ${ }^{336}$ Administrators do not have to be lawyers, ${ }^{337}$ and even if one is, then the administrator should not act as the attorney for either party in

330. Hawkins v. Comm'r, 86 F.3d 982, 988-90 (10th Cir. 1996). Even courts that are generally more conservative in their approach to ERISA requirements nonetheless caution against unduly narrow interpretations of the language within a domestic-relations order. $I d$. In rejecting a narrower approach by the Tax Court, the Tenth Circuit reasoned that nothing in the plain language of 26 U.S.C. $\S$ 414(p)(1)(A)(i) (the IRS counterpart to ERISA) mandates that domestic-relations lawyers literally mimic the statutory language when drafting orders intended to be QDROs. Id. at 990.

331. 29 U.S.C. § 1056(d)(3)(C)(i)-(iv).

332. 29 U.S.C. § 1056(d)(3)(D)(i)-(iii).

333. In re Williams, 50 F. Supp. 2d 951, 957 (C.D. Cal. 1999).

334. CARRAD, supra note 9, at 97-99.

335. Id.

336. Id. at 98 .

337. Blue v. UAL Corp., 160 F.3d 383, 386 (7th Cir. 1998). 
addition to drafting the order. ${ }^{338}$ Rather, the administrator might provide a model order and comment on whether a submitted order qualifies as a QDRO, but that is all anyone is going to get out of the administrator. $^{339}$

The attorney for the plan participant will not draft the QDRO either. ${ }^{340}$ The plan participant has a lot to lose and nothing to gain with the entry of a QDRO. ${ }^{341}$ He or she stands to lose part or all of his or her retirement benefits to an ex-spouse; thus, the participant hopes that a QDRO is never entered. ${ }^{342}$ Therefore, it is unreasonable to expect the participant's lawyer to actively assist in assigning part or all of what is probably his or her client's most significant asset. ${ }^{343}$

That leaves one other person responsible for the drafting: the attorney for the alternate payee. ${ }^{344}$ It is malpractice to fail to draft a domestic-relations order and to have it qualified by the plan administrator for the correct amounts specified by the domesticrelations court. ${ }^{345}$ When an attorney represents an alternate payee, then it is the attorney's professional and ethical responsibility "to make sure that the [drafting and] qualification process is followed through to successful completion.”346

\section{B. Delay in Drafting the QDRO}

The next question is when should the attorney draft the orderbefore, during, or after the divorce proceedings? The answer is "as soon as possible.” ${ }^{347}$ Being dilatory in sending a domestic-relations order to a plan administrator for qualification has been the subject of malpractice actions and attorney disciplinary proceedings. $^{348}$

338. CARRAD, supra note 9 , at 98 .

339. Id.

340. Id.

341. Id.

342. Id.

343. Id. Also, the participant is unlikely to want to pay his lawyer for doing this. Id.

344. Id.

345. Id.

346. Id. at 98-99.

347. Id. at 99.

348. Id. (citing Payne v. GM/UAW Pension Plan, No. 95-CV-73554DT, 1996 WL 943424, at*1-2 (E.D. Mich. May 7, 1996); Layton v. TDS Healthcare Sys. Corp., No. C-93-1827-MHP, 1994 WL 224352, at *1-5 (N.D. Cal. May 17, 1994); 
Litigation has also resulted from disparities between what the domestic-relations court ordered or what the parties agreed to compared to what the QDRO divided. ${ }^{349}$ The longer an attorney waits to draft the order, the greater the likelihood that something will be omitted from or added to the order that differs from the parties' agreement or the court's directives. ${ }^{350}$

In contested matters, the order should be drafted prior to a property-division hearing. ${ }^{351}$ Often the parties agree on most aspects of the order "except the percentage or dollar amount . . . the [a]lternate [p]ayee [will receive]."352 This is not an appropriate reason for delay. The attorney should draft the parts of the order that reflect the parties' agreement, then submit it to the plan administrator with the dollar amount or percentage left blank and a notation stating that it will be completed at a later date. ${ }^{353}$ The plan administrator will not be able to deem the draft a QDRO without the dollar amount or percentage, but this does provide the drafter a chance to learn of any other problems with the draft. ${ }^{354}$

Another issue that might arise if an order is not drafted on a timely basis is that the participant may terminate his or her employment. $^{355}$ If the participant quits his job and has a definedcontribution plan like a 401(k) or 403(b), then he may be able to start

Williams v. Law Firm of Cooch \& Taylor, No. 92C-03-024, 1994 WL 234000, at *1-4 (Del. Super. Ct. May 11, 1994); Carter v. Carter, 869 S.W.2d 822 (Mo. Ct. App. 1994); Cuyahoga Cnty. Bar Ass'n v. Williamson, 652 N.E.2d 972 (Ohio 1995); In re Disciplinary Proceedings Against Louderman, 601 N.W.2d 625 (Wis. 1999)).

349. Id. at 99-100 (citing Fortmann v. Avon Prods., Inc., No. 97 C 5286, 1999 WL 160258, at*1-9 (N.D. Ill. Mar. 9, 1999); Layton v. TDS Healthcare Sys. Corp., No. C-93-1827-MHP, 1994 WL 224352, at *1-5 (N.D. Cal. May 17, 1994); Holloman v. Holloman, 691 So. 2d 897 (Miss. 1996); Carpenter v. Carpenter, No. 01-94-01113-CV, 1996 WL 417648, at*1-6 (Tex. App. 1996); Wilson v. Wilson, 492 S.E.2d 495 (Va. App. 1997)).

350. Id. at 99 .

351. Id. at 100.

352. Id.

353. Id.

354. Id. The United States Department of Labor encourages plan administrators to provide advice and guidance to attorneys preparing domestic-relations orders as early as possible in domestic-relations proceedings. QDROs: The Division of Retirement Benefits Through Qualified Domestic Relations Orders, supra note 9, at Questions 2-1, 2-5, 2-7.

355. SHULMAN, supra note 16, § 16.02[B]. 
drawing funds from the plan immediately. ${ }^{356}$ Once a distribution is made to a participant, it is too late for a QDRO to effectively obtain the alternate payee's marital- or community-property share. ${ }^{357}$ One possible remedy is to serve a subpoena duces tecum on the plan to see if there are any funds remaining in the plan. ${ }^{358}$ If the plan funds have been depleted, then the alternate payee cannot use a QRDO to obtain what she would have received had there been money remaining in the participant's account. ${ }^{359}$

If a participant does not terminate his or her employment prior to the entry of a QDRO, then the participant may choose to retire. ${ }^{360}$ If this happens and the participant chooses to receive benefits in the form of a single-life annuity ${ }^{361}$ with no survivor benefit, then each day that goes by until a QDRO is entered costs the alternate payee the benefits that she would have otherwise received because the participant will receive payments with no obligation to share them with the alternate payee. ${ }^{362}$ When the QDRO is eventually entered, it is possible for the alternate payee to recover lost payments, but only on a prospective basis because ERISA forbids retroactive payments. ${ }^{363}$ For example, if an alternate payee lost $\$ 1,000$ because the retiring participant chose a single-life annuity before the entry of a QDRO, then the QDRO can include a provision stating that the alternate payee will receive an additional amount per month until the $\$ 1,000$ is fully recovered. ${ }^{364}$ The participant, however, must consent to this. If there is no consent, then the matter must be decided by a court, and it is not the most tenable position to argue that the alternate payee should receive lost money despite the fact that his or her lawyer failed to draft the order before the participant retired.

There is a second problem for alternate payees when it comes to the retirement of participants before the entry of a QDRO- the loss

356. Id.

357. Id.

358. Id.

359. Id.

360. Id. § 16.02[C].

361. 29 U.S.C. $\S 1055(d)(1)(B)$ (2006 \& Supp. IV 2010) (providing that a singlelife annuity is an annuity payable for the life of one person).

362. SHULMAN, supra note 16, § 16.02[C].

363. 29 U.S.C. § 1056(d)(3)(H)(iv).

364. SHULMAN, supra note 16, § 16.02[C]. 
of a lifetime stream of income. ${ }^{365}$ When a participant chooses a single-life annuity, payments cease when the participant dies. ${ }^{366} \mathrm{~A}$ properly drafted QDRO can require the participant to choose a qualified joint-and-survivor annuity, ${ }^{367}$ which would guarantee the alternate payee a lifetime stream of payments. It is essential to have the QDRO entered before the participant retires; otherwise, the alternate payee has to hope that the participant outlives her so that she can receive a lifetime stream of payments. ${ }^{368}$

The death of the plan participant before the entry of a QDRO could also have adverse consequences for an alternate payee. ${ }^{369}$ Some plan administrators take the position that an order cannot be qualified as a QDRO if the participant dies before the QDRO qualification process is complete. ${ }^{370}$ If this happens, then there are two things that the alternate payee's attorney can do.

First, if occurs, a court may construe the divorce decree, propertysettlement agreement, or separation agreement as a QDRO if enough information is included about the identities and addresses of the participant and the alternate payee, the duration and amount of benefits owed to the alternate payee, and the name of the benefit plan. ${ }^{371}$ Likewise, if one of the foregoing documents contains survivorship-benefits language, then a plan administrator may agree to lifetime benefits for the alternate payee. ${ }^{372}$

Second, the plan might accept a nunc pro tunc ${ }^{373}$ QDRO. ${ }^{374}$ If so, the alternate payee's benefits might not be jeopardized. If the plan does not accept nunc pro tunc QDROs, then it might be worth suing the plan to put the matter before a judge, depending on the federal circuit where the case is. Some circuits hold the view that

365. Id.

366. 29 U.S.C. § 1056(d)(3)(H)(iv).

367. 29 U.S.C. § 1055(d)(1).

368. SHULMAN, supra note $16, \S 16.02[\mathrm{C}]$.

369. Id. § 16.02[D].

370. Id.

371. Id.

372. Id.

373. Black's LAW DictionaRy 1174 (9th ed. 2009) (defining nunc pro tunc as "[h]aving retroactive legal effect through a court's inherent power”).

374. SHULMAN, supra note 16, § 16.02[D]. 
posthumous QDROs that otherwise comply with the REA are acceptable, ${ }^{375}$ but others have held that they are not. ${ }^{376}$

375. Patton v. Denver Post Corp., 326 F.3d 1148, 1152-54 (10th Cir. 2003) (stating that an ex-spouse's retroactively dated QDRO to before the plan participant's death is valid); Hogan v. Raytheon, Co., 302 F.3d 854, 857 (8th Cir. 2002) (allowing for posthumous entry of a QDRO where the plan had notice prior to death, but notice was not essential to validity); Trs. of the Dirs. Guild of Am.Producer Pension Benefits Plans v. Tise, 234 F.3d 415, 425-26 nn.9-10 (9th Cir. 2000). The Tise court held that a post-death QDRO is valid, provided that the plan has notice before death of the impending claim. Id. The court did not decide whether a QDRO could issue after a participant's death if the plan had no notice of the domestic-relations order prior to the death. Id. The court also did not decide whether the state court properly granted a nunc pro tunc order or whether the Full Faith and Credit statute, 28 U.S.C. $\S 1738$, would require a federal court to honor a nunc pro tunc order. Id. But see Carmona v. Carmona, 544 F.3d 988, 993, 998, 1000-04 (9th Cir. 2008). In Carmona, the Ninth Circuit appeared to have moved away from Tise when it followed Hopkins v. AT\&T Global Info. Solutions Co., 105 F.3d 153, 157 (4th Cir. 1997), but did not adopt its entire rationale. Carmona, 544 F.3d at 993. The court held that a participant's spouse has an irrevocable right to a qualified joint-and-survivor annuity on the annuity start date, and that right cannot be assigned to a subsequent spouse. Id. The court identified the question before it as "whether a . . . 'participant's retirement cuts off [the] putative alternate payee's right to obtain [a] . . . QDRO' with [respect] to . . . surviving spouse benefits.” Id. at 1000 . The court said that Tise left that question open. Id. at 1001. The court did, however, reaffirm its holding in Tise that as long as a valid domestic-relations order creates an alternate payee's legally enforceable property right in a pre-retirement survivor annuity, a posthumous QDRO can be obtained. Id. at 1004. See also Torres v. Torres, 60 P.3d 798, 805-06, 817, 822-23 (Haw. 2002). The Supreme Court of Hawaii relied on Tise to hold that survivor benefits did not vest in the participant's widow on the date of his eligibility for retirement or upon his death. Torres, 60 P.3d at 822. The court affirmed the trial court's order amending the initial divorce decree after the participant's death so it could be qualified as a QDRO, stating that “[a]s long as ERISA's qualification requirements are met, any DRO permissible under state domestic-relations law should be binding upon a pension plan.” Id. at 817 .

376. Samaroo v. Samaroo, 193 F.3d 185, 186, 190-91 (3d Cir. 1999) (stating that a posthumous QDRO is invalid). But see Files v. ExxonMobil Pension Plan, 428 F.3d 478, 479, 487-88 (3d Cir. 2005). In Files, the Third Circuit retreated from the full implications of Samaroo, reiterating that Samaroo was "expressly limited to its facts." Files, 428 F.3d at 487. The court held that a property-settlement agreement granting an unmarried pension-plan participant's former spouse a separate interest in $50 \%$ of the participant's pension as of the date of the agreement constituted a QDRO pursuant to 29 U.S.C. $§$ 1056(d)(3) (2006), "providing the exwife with a separate interest in the pension benefit prior to her ex-husband's death." Id. at 479. The court concluded that Samaroo did not control because the former spouse in Files was seeking a survivorship benefit provided for in the agreement. 


\section{Insufficient Understanding of How Annuities Are Divided}

If an ERISA-qualified plan offers the employee the option to receive his benefits in the form of an annuity, then there are typically three ways for the annuity to be paid: “(1) as a Single Life Annuity for the Participant's life only[;] (2) as a Qualified Joint and Survivor Annuity for the lives of the Participant and the Alternate Payee[;] or (3) as a Qualified and Joint Survivor Annuity involving the Participant and his new spouse." ${ }^{377}$ Regardless of how the annuity is ultimately paid, the present actuarial value for the different payment methods must be the same so that the total amount that the plan pays will be the same. ${ }^{378}$ "Present Actuarial Value is [today's] value . . . of an amount of money on hand in the future . . . or a stream of payments [owed] in the future." ${ }^{379}$ For example: If you have $\$ 10$ and invest it at 5\% annual interest, then in one year it will be worth $\$ 10.50$, which makes the present value of $\$ 10.50$ one year from now equal to $\$ 10$ in current dollars. ${ }^{380}$

Similarly, a fixed amount in current dollars can be compared to a series of future payments. ${ }^{381}$ For example: Using the same $5 \%$ annual interest rate mentioned above, if a person makes payments of \$10 per month for twelve consecutive months and starts those payments in four years, then she will need to have $\$ 121.55$ four years from now to fund those future payments. ${ }^{382}$ Hence, "the present value of a stream of [twelve] monthly payments of $\$ 10 \ldots$ starting four years from today[] is $\$ 100$. ."383 Thus, one can say that "the value of $\$ 100$ on hand today and the value of a stream of [twelve] monthly payments

Id. at 487. The court also distinguished Hopkins v. AT\&T Global Info. Solutions Co., 105 F.3d 153, 157 (4th Cir. 1997), on the grounds that Hopkins involved "an attempt to divest benefits already vested in a subsequent spouse, whereas [in Files], there was no such vesting.” Id. at 487-88 n.12. See also Rivers v. Cent. \& S. W. Corp., 186 F.3d 681, 683 (5th Cir. 1999) (ruling that a post-retirement QDRO is not valid); Hopkins v. AT\&T Global Info. Solutions Co., 105 F.3d 153, 157 (4th Cir. 1997) (ruling that a post-retirement QDRO is not valid).

377. CARRAD, supra note 9 , at 80.

378. See 29 U.S.C. $§$ 1056(d)(3)(D)(ii) (2006). Under ERISA, a plan cannot be required to provide increased benefits to an alternate payee determined on the basis of actuarial value. $I d$.

379. CARRAD, supra note 9 , at 74 .

380. Id.

381. Id. at 75 .

382. Id.

383. Id. 
of $\$ 10$ each commencing four years from today are actuarially equivalent." ${ }^{384}$ It is also possible to compare the values of two different series of payments to be made in the future to determine if one series is equal to the other on an actuarial basis. ${ }^{385}$

For example: A fifty-five-year-old man (Husband) has a fortyyear-old wife (Wife). ${ }^{386}$ He plans to retire at the age of sixty-five and receive pension payments of $\$ 1,000$ per month for the remainder of his life. ${ }^{387}$ His life expectancy is eighty. ${ }^{388}$ Husband and Wife are in a divorce proceeding, and she wants to start receiving her marital share of his pension payments now. ${ }^{389}$ Her life expectancy is eighty-five. ${ }^{390}$ The domestic-relations court enters an order awarding Wife $50 \%$ of Husband's pension benefits. ${ }^{391}$ It would be a serious error to conclude that she is entitled to $\$ 500$ of his $\$ 1,000$ monthly payment. $^{392}$ She will start receiving her stream of payments now, but he will not start receiving his for a decade. Once the payments start, her income stream will last for forty-five years, while his will last for fifteen years. ${ }^{393}$ Because her income stream starts earlier and will last longer than his, her payments must be less than $\$ 500$ to comply with ERISA's mandate that a QDRO cannot order a plan to pay more in benefits than the plan provides. ${ }^{394}$ In fact, her payments must be significantly less than $\$ 500$ as demonstrated by the following example. At an annual interest rate of 5\%, her payments would have to be $\$ 178.90$ per month for forty-five years to be actuarially equivalent to the $\$ 821.10$ per month that the Husband will start getting ten years after she starts receiving her payments. ${ }^{395}$ This circumstance exists because she will start receiving payments a decade before he starts receiving his, and she will get paid for fortyfive years compared to his fifteen. ${ }^{396}$

384. Id.

385. Id.

386. Id.

387. Id.

388. Id.

389. Id. at 76.

390. Id.

391. Id.

392. Id.

393. Id.

394. Id.

395. Id.

396. Id. 
For readers who are domestic-relations practitioners and not financial analysts, statisticians, or actuaries-do not panic. ERISA does not mandate that an attorney be an actuary to draft a QDRO. ${ }^{397}$ An attorney, however, does have to understand actuarial equivalence and how it relates to interest rates, timing of payments, and mortality rates. ${ }^{398}$ Just remember the basics: The longer the payments last, the smaller they have to be; conversely, the shorter the payments last, the larger the payments must be. If you start with the amount that will be used to make a series of periodic future payments, then those payments can be made by paying the recipient a larger amount for a shorter period of time or a smaller amount for a longer period of time. ${ }^{399}$ Now, back to dividing annuities.

As previously mentioned, there are typically three ways for a plan participant to receive his annuity payments: “(1) as a Single Life Annuity for the Participant's life only[;] (2) as a Qualified Joint and Survivor Annuity for the lives of the Participant and the Alternate Payee[;] or (3) as a Qualified Joint and Survivor Annuity involving the Participant and his new spouse." 400 Once an election is made from the three choices, there are five distinct methods of splitting the payments between the participant and his or her former spouse. ${ }^{401}$

\section{Participant is Retired and Receiving Payments}

If the participant is retired and receiving payments from her plan, then an alternate payee has no options regarding the form or amount of benefits that she will receive because the plan started making payments to the participant based on certain actuarial assumptions, and the plan is entitled to rely on those assumptions. ${ }^{402}$ The plan administrator cannot be compelled to actuarially adjust the alternate

397. Id. at 76 .

398. Id. at $76-77$.

399. Id. at 80-81.

400. Id. at 80 .

401. Id. at 81 .

402. Id. But see In re Marriage of Allison, 234 Cal. Rptr. 671, 674 (Cal. Ct. App. 1987) Under California law, "one spouse [could not], by invoking a condition wholly within his control, defeat the community interest of the other spouse[,]" and "[b]y opting to retire in the brief period between the judgment of dissolution and the division of property, [the] husband attempted to do just that.” Id. The court remedied the situation by awarding the wife a monetary amount equal to the actuarial value of her forfeited interest. $I d$. 
payee's payments to last for her lifetime. ${ }^{403}$ Under this circumstance, payments to the alternate payee will cease on the participant's death. $^{404}$

\section{Single-Life Annuity on the Life of the Participant}

If the participant is still working and chooses a single-life annuity based on his life expectancy, then he will start receiving payments when the he retires, and payments will end at his death. ${ }^{405}$ The alternate payee facing this situation has to hope that the participant outlives her if she wants to receive benefits for her lifetime. ${ }^{406}$

\section{Qualified Joint-and-Survivor Annuity on the Lives of the Participant and Alternate Payee}

This approach guarantees the alternate payee a lifetime stream of payments. To secure this benefit, however, the attorney must insert language in a QDRO that designates the alternate payee as the spouse of the participant for the purpose of having the participant elect a qualified joint-and-survivor annuity with the alternate payee. ${ }^{407}$

\section{Qualified Joint-and-Survivor Annuity on the Lives of the Participant and the New Spouse}

If the participant is remarried, then he may choose to elect a qualified joint-and-survivor annuity with his current spouse. ${ }^{408}$ This does not preclude the former spouse from receiving a stream of payments that can continue past the participant's death. ${ }^{409}$ Payments to the alternate payee will continue until the later of the death of the participant or his current spouse, but only if appropriate language is included in a QDRO. ${ }^{410}$

403. CARRAD, supra note 9 , at 83 .

404. Id.

405. Id. at 82 .

406. Id.

407. Id.; see 29 U.S.C. § 1055(a)(1), (d) (2006 \& Supp. II 2009); 29 U.S.C. § 1056(d)(3)(F) (2006).

408. CARRAD, supra note 9, at 82; 29 U.S.C. § 1055(c)(2).

409. CARRAD, supra note 9 , at 82 .

410. Id. at 82-83. 
5. Single-Life Annuity on the Life of the Alternate Payee

This is the preference of a majority of alternate payees because it gives them complete control over when the payments start, and there is no risk of outliving the payments. ${ }^{411}$

It is essential that attorneys in domestic-relations proceedings explain these options and the consequences flowing from each one to their clients. ${ }^{412}$ This can be quite the task depending on the client's level of education and sophistication. Moreover, depending on what might happen to the participant's employment or life prior to the entry of a QDRO, an alternate payee's options can be narrowed significantly. Thus, it is vital to have an order drafted and qualified as soon as possible to preserve the maximum number of options for the client.

\section{Uncritically Using the Plan's Model QDRO}

Many plan administrators will provide attorneys with a companygenerated model QDRO. This is done in part to follow Department of Labor guidelines $^{413}$ that require plan administrators to provide information about plans and plan benefits as early as possible in domestic-relations proceedings. ${ }^{414}$ Mostly though, this is done so that the administrator's review and approval of the order as a QDRO will be easier and less costly. ${ }^{415}$ Plan administrators want to simplify their work and minimize the costs associated with the review-and-approval process. Therefore, the model orders provided to lawyers are not designed to obtain the maximum benefits for alternate payees - that is the responsibility and duty of the alternate payee's lawyer. ${ }^{416} \mathrm{~A}$ plan administrator cannot, however, refuse to qualify a domesticrelations order simply because the drafter did not use the company's

411. Id. at 83 .

412. Id. at 96.

413. The Department of Labor has issued QDRO “guidelines" rather than regulations because the authority to issue ERISA regulations lies with the Department of the Treasury. See, e.g., CARRAD, supra note 9, at 407; Gen. Motors Corp. v. Buha, 623 F.2d 455, 461-62 (6th Cir. 1980) (citation omitted).

414. QDROs: The Division of Retirement Benefits Through Qualified Domestic Relations Orders, supra note 9, Question 2-1.

415. CARRAD, supra note 9, at 100-01; SHULMAN, supra note 16, § 13.01.

416. CARRAD, supra note 9, at 100-01; SHULMAN, supra note 16, § 13.01. 
model form. ${ }^{417}$ The administrator must accept any domestic-relations order that satisfies the REA's QDRO requirements. ${ }^{418}$ The following are frequent omissions from employers' model QDROs. ${ }^{419}$

\section{No Survivorship Protection}

Typically, model QDROs do not include clauses that provide survivorship benefits to alternate payees such as qualified preretirement survivor annuities (QPSA) or qualified joint-and-survivor annuities (QJSA). ${ }^{420}$ To guarantee that the alternate payee will receive benefits after the participant's death, the QDRO must explicitly state that the alternate payee will be treated as the participant's surviving spouse with respect to a QPSA and QJSA to the extent of her assigned benefits under the QDRO. ${ }^{421}$ Some employers pay the costs associated with providing their employees with a pre-retirement-annuity benefit. ${ }^{422}$ Some, however, do not. ${ }^{423}$ Regardless, to make sure the benefit remains available to an alternate payee, her lawyer must include language in the QDRO that requires the participant to maintain coverage for the life of the benefit or bars him from opting out of such coverage. ${ }^{424}$

417. QDROs: The Division of Retirement Benefits Through Qualified Domestic Relations Orders, supra note 9, Question 2-7.

418. Id. Likewise, an administrator cannot reject a domestic-relations order because the order omits information within the administrator's knowledge or information that he can easily obtain from a simple phone call, fax, or email to the lawyer who submitted the order. Id. Nevertheless, the drafter should try to be scrupulous in complying with the QDRO requirements because each day that the QDRO is not entered could work to the detriment of the client, particularly if she is an alternate payee. $I d$.

419. See text accompanying notes 420-551, infra.

420. CARRAD, supra note 9, at 102-03; SHULMAN, supra note 16, § 13.01[A].

421. See CARRAD, supra note 9, at 102-03; see also RAYMOND S. DIETRICH, QuALIFIED DOMEstic Relations ORDERS: STRATEgy AND LIABILITY FOR THE FAMILY LAW ATtORNEY § 1.02 (9th ed. 2009); DAVID A. PRATT \& SHARON REECE, ERISA AND EMPLOYEE BENEFIT LAW-The EsSENTIALS 435-36 (2010); SHULMAN, supra note 16, § 13.02[A]-[C].

422. See, e.g., CARRAD, supra note 9 , at 72 .

423. SHULMAN, supra note 16, § 13.01[A].

424. See generally DieTRICH, supra note 421, § 1.02; PRATT \& REECE, supra note 421, at 435-42; SCHNEIDER \& PINHEIRO, supra note 30, § 3.11[B]; SHULMAN, supra note 16, § 13.01[A]. 
2. No Division of the Participant's Tax Basis in Defined-Contribution Plans

Employees can make contributions to defined-contribution plans on a before-tax and after-tax basis, and the employer can also make contributions. $^{425}$ Employees benefit from after-tax contributions because when they receive distributions, they pay taxes not on the entire distribution, but on the difference between the entire distribution and the amount of the distribution constituting after-tax contributions. ${ }^{426}$ For example: If a person sells an asset for more than she paid for it, then she will not owe taxes on the entire sale price; rather, she will owe taxes on the difference between the sale price and the price she originally paid for the asset before she sold it. ${ }^{427}$ The asset price that she originally paid is called her basis. ${ }^{428}$ Likewise, the total of an employee's after-tax contribution to her retirement plan is considered her basis; thus, she is not taxed a second time when she receives a withdrawal containing after-tax contributions. ${ }^{429}$ An alternate payee who is entitled to receive $50 \%$ of a participant's plan benefits should insist on receiving $50 \%$ of the participant's basis; otherwise, she will end up with less than $50 \%$ of the assets because of the tax consequences. ${ }^{430}$

For example: Assume that a participant has $\$ 200,000$ in a 401(k) or 403(b) that a court divides equally between him and his spouse, and his basis in that balance is $\$ 40,000 .^{431}$ Assume further that both parties are in a $31 \%$ individual income-tax bracket. ${ }^{432}$ If the alternate payee receives no part of the participant's tax basis, then her post-tax share of the benefits will be $\$ 69,000$ ( $\$ 100,000$ marital share - 31\% tax of $\$ 31,000)$. $^{43}$ The participant's post-tax share will be $\$ 81,400$ $(\$ 100,000$ marital share $-\$ 40,000$ basis $=\$ 60,000$ taxable amount; $31 \%$ tax on $\$ 60,000=\$ 18,600 ; \$ 100,000$ marital share $-\$ 18,600$ tax $=\$ 81,400) .{ }^{434} \mathrm{~A}$ person would have an extremely difficult, if not

425. See PRATT \& REECE, supra note 421, at 323-25.

426. See id.

427. CARRAD, supra note 9, at 103.

428. PRATT \& REECE, supra note 421, at 325.

429. Id.

430. CARRAD, supra note 9, at 103-04.

431. Id.

432. Id.

433. Id.

434. Id. at 103-04, 147-48. 
impossible, time explaining to an alternate payee why she received $\$ 12,400$ less than her ex-spouse when a court explicitly ordered that she receive one-half of a $\$ 200,000$ benefit.

To avoid this disparity, the attorney should include a provision in the QDRO that grants the alternate payee a percentage of the participant's tax basis equal to the percentage of the plan assets assigned to her in the order. ${ }^{435}$ The language can simply state that the alternate payee should receive 50\% (or whatever percent she received of the participant's plan benefits) of the participant's basis in his account as of a certain date. ${ }^{436}$ This difference is significant, as demonstrated using the facts from the previous example: The participant has $\$ 200,000$ in a $401(\mathrm{k})$ or $403(\mathrm{~b})$ that a court divides equally between him and his spouse, and his basis in that balance is $\$ 40,000$. Both parties are in a 31\% tax bracket. If the alternate payee receives one-half of the participant's tax basis, then her after-tax share of the benefits will be $\$ 75,200$ (\$100,000 marital share 20,000 one-half of the participant's basis $=\$ 80,000$ taxable amount; $31 \%$ tax on $\$ 80,000=\$ 24,800 ; \$ 100,000$ marital share $-\$ 24,800$ tax $=\$ 75,200)$. The participant's after-tax share will also be $\$ 75,200$ $(\$ 100,000$ marital share $-\$ 20,000$ one half basis $=\$ 80,000$ taxable amount; $31 \%$ tax on $\$ 80,000=\$ 24,800 ; \$ 100,000$ marital share $\$ 24,800$ tax $=\$ 75,200)$.

Most employers' model QDROs do not contain a provision addressing the allocation of the participant's tax basis because the plan has no reason to concern itself with the parties' tax situations. ${ }^{437}$ The alternate payee's attorney has a duty to ensure that she is not short-changed by failing to receive her marital share of her former spouse's tax basis. Relying on the employer's model QDRO will not fulfill this duty.

\section{No Provision for Cost-of-Living Adjustments}

Some plan participants who receive monthly payments from their benefit plans receive periodic increases in those payments to offset the effects of inflation. These increases are called cost-of-living adjustments. ${ }^{438}$ Hardly any model QDROs will include a provision

435. Id.

436. Id.

437. Id.

438. Id. at 104; SHULMAN, supra note 16, § 13.02[I]. 
granting the alternate payee a share of the participant's cost-of-living adjustments. ${ }^{439}$ This benefits the participant because she will receive not only her share of the increase, but also her former spouse's share. This result can be avoided, however, by including language in the QDRO that awards the alternate payee a pro rata share of the participant's cost-of-living adjustments. ${ }^{440}$

\section{No Early Retirement Subsidy Allocation}

Some employers offer their employees an attractive monetary incentive to retire early. ${ }^{441}$ For example: If a company's pension plan allows a worker to retire at age sixty and still receive the same benefits that he would have received at the normal retirement age, ${ }^{442}$ then the company is subsidizing the employee's early retirement. ${ }^{443}$ Under the ERISA provision addressing the form and payment of benefits, ${ }^{444}$ an alternate payee who elects to start receiving monthly payments after the participant reaches the plan-defined earliest retirement age, ${ }^{445}$ but before he actually retires, cannot receive a share of the early retirement subsidy. ${ }^{446}$ This is because the employer offered the subsidy to entice workers to retire earlier than they would have otherwise. And unless the workers do retire, the employer will

439. CARRAD, supra note 9, at 104; SHULMAN, supra note 16, § 13.02[I].

440. CARRAD, supra note 9, at 104; SHULMAN, supra note 16, § 13.02[I].

441. CARRAD, supra note 9, at 104-05; DIETRICH, supra note 421, § 10.04[4]; PRATT \& REECE, supra note 421, at 126-28; SCHNEIDER \& PINHEIRO, supra note 30, § 3.13[A]; SHULMAN, supra note 16, § 13.02[C].

442. 29 U.S.C. $\S 1002(24)$ (2006) (providing that normal retirement age means "the earlier of (A) the time a plan participant attains normal retirement age under the plan, or (B) the later of (i) the time a plan participant attains age 65, or (ii) the 5th anniversary of the time a plan participant commenced participation in the plan”). In order to make sense of this definition, calculate it backwards, i.e., first decide the later of parts (B)(i) and (B)(ii), then compare that to part (A). CARRAD, supra note 9, at 14-15. Calculate the date of the fifth anniversary of the date the participant joined the plan (which may not coincide with the start of employment because ERISA allows employers to require their employees to work for one year before participating in the retirement plan). Id. at 15. Next, determine the date the participant will turn sixty-five, and select the later of these two dates. Id. Compare that date with the date that the participant will reach the normal retirement age specified in the text of the plan, and choose the earlier of these two dates. Id.

443. CARRAD, supra note 9, at 104-05; SHULMAN, supra note 16, § 13.02[C].

444. 29 U.S.C. § 1056.

445. 29 U.S.C. $\S 1056(d)(3)(E)(i i)$.

446. 29 U.S.C. § 1056(d)(3)(E)(i)(II). 
not get what it paid for. Therefore, it would not be fair for the employer to be forced to pay the alternate payee part of an early retirement subsidy that it did not benefit from offering. ${ }^{447}$

On the other hand, if the alternate payee chooses to start receiving payments after the participant reaches the plan-defined early retirement age and the participant retires before the plan-defined normal retirement age, then the employer will owe the participant the early retirement subsidy. ${ }^{448}$ In this instance, the alternate payee can receive a proportionate share of the early retirement subsidy, but only if the QDRO explicitly says that she can. ${ }^{449}$ The employer's model QDRO almost never contains language awarding the alternate payee her proportionate share of the participant's early retirement subsidy when the participant retires after reaching the early retirement age but before the normal retirement age. ${ }^{450}$ The alternate payee's lawyer will have to make sure that the QDRO includes such language. ${ }^{451}$

\section{Provision for Misdirected Payments}

Despite ever-advancing technology and the highly developed knowledge, skill, and sophistication of plan administrators, mistakes can still happen in the process of paying benefits to participants and alternate payees. $^{452}$ Occasionally, a plan may send a payment intended for the alternate payee to the participant instead. ${ }^{453}$ The plan's model QDRO will not address what should be done in this instance because the plan's only concern is to avoid overpayment. ${ }^{454}$ Language should be included in the QDRO that requires the participant who receives a payment intended for the alternate payee to return the money to the plan administrator with a request that the funds be forwarded to the alternate payee. ${ }^{455}$ The participant should not forward the payment to the alternate payee directly because the party receiving the payment is responsible for paying the income

447. CARRAD, supra note 9, at 105.

448. Id.; SHULMAN, supra note 16, § 13.02[C].

449. CARRAD, supra note 9, at 105; SHULMAN, supra note 16, § 13.02[C].

450. CARRAD, supra note 9, at 105; SHULMAN, supra note 16, § 13.02[C].

451. CARRAD, supra note 9, at 105; SHULMAN, supra note 16, § 13.02[C].

452. SHULMAN, supra note $16, \S 11.06[\mathrm{~N}]$.

453. Id.; see also CARRAD, supra note 9, at 105-06.

454. CARRAD, supra note 9, at 106.

455. Id. at 105-06; SHULMAN, supra note 16, § 11.06[N]. 
taxes on the payment. ${ }^{456}$ If the participant does not involve the plan administrator in correcting the misdirected payment, then the participant will owe taxes on the payment intended for the alternate payee. $^{457}$

The plan administrator can spare the participant any unwanted tax consequences by forwarding the misdirected payment to the alternate payee and then issuing the participant an IRS Form 1099 that would relieve him of any taxes associated with the misdirected payment. ${ }^{458}$ The language regarding the Form 1099 should be included with the language that requires the participant to return misdirected payments to the plan administrator. ${ }^{459}$

\section{The $10 \%$ Penalty on Early Distributions}

Following a divorce, many alternate payees want immediate access to their shares of their ex-spouses' retirement benefits. It is possible for them to get their money immediately, but they should be advised that doing so will trigger a $10 \%$ penalty that is payable if a distribution is taken from an ERISA-qualified plan before the participant reaches the age of fifty-nine. ${ }^{460}$ The plan's model may state that the alternate payee will be paid directly from the plan, and this may be fine with the alternate payee if she is willing to pay the $10 \%$ penalty. ${ }^{461}$ On the other hand, an alternate payee may not want to pay the penalty and instead may want her share of the benefits rolled over into an IRA or her own retirement plan. ${ }^{462}$ In this case, the QDRO must require the plan administrator to transfer the money from the plan into the IRA. ${ }^{463}$ If she wants her share of the benefits rolled over into her own retirement plan, then the QDRO must instruct the plan administrator to do so. ${ }^{464}$

456. SHULMAN, supra note $16, \S 11.06[\mathrm{~N}]$.

457. Id.

458. Id.

459. Id.

460. CARRAD, supra note 9, at 106.

461. Id.

462. DIETRICH, supra note 421, § 17.02; SCHNEIDER \& PINHEIRO, supra note 30, $\S 3.11[\mathrm{~B}][6]$.

463. SCHNEIDER \& PINHEIRO, supra note 30, § 3.11[B][6].

464. DiETRICH, supra note 421, § 17.02; PRATT \& REECE, supra note 421, at 145-46; SCHNEIDER \& PINHEIRO, supra note 30, § 3.11[B][6]. 
The alternate payee should not take a payment directly from the plan and deposit the funds herself into an IRA or her own retirement plan. ${ }^{465}$ Once the money is in her hands, the $10 \%$ penalty is triggered regardless of how quickly she deposits it into an IRA or her own retirement plan. ${ }^{466}$ The QDRO should be properly drafted to avoid triggering the $10 \%$ early withdrawal penalty. ${ }^{467}$

\section{Always Using a Shared-Interest Approach with Defined-Benefit Plans}

\section{a. Separate-Interest Approach}

Benefits payments under a defined-benefit plan will be made under a either a separate-interest approach or a shared-interest approach. ${ }^{468}$ Under the separate-interest approach, the amount of the alternate payee's payments will be based on her life expectancy. ${ }^{469}$ For example: A divorced participant retired with a monthly pension of $\$ 2,000$, and the court awarded the alternate-payee, the participant's former spouse, one-half of his monthly benefits based on a separateinterest approach. ${ }^{470}$ The alternate payee is ten years younger than the participant. $^{471}$ The alternate payee will not receive $\$ 1,000$ per month; ${ }^{472}$ instead, she will receive about $\$ 700$ per month because she will be paid over a longer period of time due to her longer life expectancy. ${ }^{473}$ A QDRO directing the plan to pay the alternate payee one-half of the participant's monthly benefits for the alternate payee's lifetime would be rejected by the plan administrator as violating ERISA's prohibition against requiring the plan to pay increased benefits based on actuarial equivalence. ${ }^{474}$

465. CARRAD, supra note 9 , at 106.

466. Id.

467. Id.

468. DIETRICH, supra note 421, § 10.02; SHULMAN, supra note 16, § 6.01.

469. DIETRICH, supra note 421, § 10.02[2]; PRATT \& REECE, supra note 421, at 130; SHULMAN, supra note $16, \S 6.01$.

470. SHULMAN, supra note $16, \S 6.02$.

471. Id.

472. Id.

473. Id.

474. ShULmAN, supra note $16, \S 6.02$. A plan cannot be required to pay more in benefits than specified in the text of the plan. 29 U.S.C. § 1056(d)(3)(D)(ii) (2006). 
Another point to keep in mind is that even if the QDRO provides that the plan should use a separate-interest approach the language must be unambiguous. ${ }^{475}$ The drafter should not merely state that the QDRO is a separate-interest order. ${ }^{476}$ Instead, the drafter should provide that the parties intend to use a separate-interest approach and that the alternate payee's benefits should be calculated based on her life expectancy. ${ }^{477}$ Also, a provision should be added stating that the alternate payee's benefits will not end when the participant dies. ${ }^{478}$

Under the separate-interest approach, the alternate payee can start receiving benefits before the participant retires, provided that the commencement date is on or after the participant reaches the earliest retirement age. ${ }^{479}$ If the alternate payee cannot wait or does not want to wait to start receiving benefits, then the separate-interest approach allows her to start receiving benefits at her discretion. But, she should be advised that if she starts receiving benefits before the participant reaches the earliest retirement age, then she will lose her entitlement to a proportionate share of his early retirement subsidy. ${ }^{480}$ The longer she waits to commence receiving benefits, the larger those benefits will be. ${ }^{481}$ The separate-interest approach is also advantageous to the participant. ${ }^{482}$ If the participant is single when he retires, then "he can

475. SHULMAN, supra note 16 , § 6.02 .

476. Id.

477. Id.

478. Id.

479. Id. 29 U.S.C. § 1056(d)(3)(E)(ii) provides the following:

[T] he term "earliest retirement age" means the earlier of-(I) the date on which the participant is entitled to a distribution under the plan, or (II) the later of [either] the date [that] the participant attains age 50 or the earliest date on which the participant could begin receiving benefits under the plan if the participant separated from service.

$\S 1056(d)(3)(E)(i i)$.

To make sense of this definition, calculate it backwards, i.e., first determine the later of the two dates in (II), i.e., the date the participant turns fifty-years-old and the earliest date he could begin receiving benefits under the plan if he separated from service. CARRAD, supra note 9, at 15. Next, compare that date to date in (I), i.e., the date the participant is entitled to a distribution under the plan, and the earliest of these two dates is the earliest retirement age. CARRAD, supra note 9, at 15.

480. SHULMAN, supra note $16, \S 6.02[\mathrm{~A}]$.

481. Id.

482. Id. 
elect to receive benefits in the form of a single life annuity," or if he is remarried, then he can provide survivorship coverage to his new spouse by choosing a qualified joint-and-survivor annuity based on his and her life. ${ }^{483}$

A separate-interest QDRO must still include a provision for a $\mathrm{QPSA}^{484}$ to guarantee that the alternate payee will receive her share of the participant's benefits if he dies before he retires or before he starts receiving benefits under the plan. ${ }^{485}$ With a properly drafted separate-interest QDRO, the alternate payee will receive a lifetime stream of income once the payments start. Her attorney, however, will need to make sure that those payments get started even if the participant dies before she does, and a provision granting her a QPSA will do just that. ${ }^{486}$ If the QDRO does not provide for pre-retirement annuity protection, then the alternate payee will stop receiving benefits when the participant dies. ${ }^{487}$

A properly drafted separate-interest QDRO should not include a provision that grants the alternate payee a qualified joint-and-survivor annuity with the participant because she is already guaranteed a lifetime stream of income once the payments start. ${ }^{488}$ Granting her the lifetime guarantee and a qualified joint-and-survivor annuity would deprive the participant of his right to elect to do whatever he wants with his separate share, such as a single-life annuity on a nonactuarially reduced basis or a qualified joint-and-survivor annuity with his current spouse. ${ }^{489}$

\section{b. Shared-Interest Approach}

The second way to divide pension payments under a definedbenefit plan is the shared-interest approach. ${ }^{490}$ Under this approach, the alternate payee's share of the participant's benefits is not

483. Id.

484. 29 U.S.C. $\S 1055(\mathrm{e})$.

485. DIETRICH, supra note 421, § 10.04[1]; PRATT \& REECE, supra note 421, at 436, 439; SCHNEIDER \& PINHEIRO, supra note $30 § 3.11[\mathrm{~B}][4]$; SHULMAN, supra note $16, \S 6.02[\mathrm{~B}]$.

486. SHULMAN, supra note 16, § 6.02[B].

487. PRATT \& REECE, supra note 421, at 132; ShULMAN, supra note 16, § 6.02[B]

488. SHULMAN, supra note $16, \S 6.02[\mathrm{~B}]$.

489. Id.

490. Id. 
actuarially adjusted to her life; rather, she shares in the participant's benefits when he starts receiving them. ${ }^{491}$ This means that the alternate payee cannot start receiving benefits until the participant retires, and even then, the payments cease when the participant dies. ${ }^{42}$ The only way to keep the payments going after the death of the participant is to include pre-retirement and post-retirement survivorship clauses. ${ }^{493}$ For example: A participant is entitled to a $\$ 2,000$ monthly benefit, and the court divides it evenly between the participant and the alternate payee, who is fifteen years younger. The alternate payee will receive $\$ 1,000$ per month with no actuarial reduction because the benefits are tied to the participant's life rather than her own. If a separate-interest QDRO is used instead, then she will receive $\$ 600$ per month, but she will receive it for her lifetime. If she wants to receive the $\$ 1,000$ monthly benefit for the remainder of her life, the participant has to outlive her. ${ }^{494}$

An alternate payee in this situation should protect herself by having the QDRO provide for a QPSA and a QJSA. ${ }^{495}$ Using the preceding example, if the QDRO contains QPSA and QJSA clauses, then the pension plan would actuarially adjust the monthly pension from $\$ 2,000$ per month to $\$ 1,800$. The participant and the alternate payee would receive $\$ 900$ per month while they are both living. If the participant predeceases the alternate payee, then the alternate payee will still receive $\$ 900$ for her lifetime based on the QJSA provision in the QDRO. Likewise, if the participant dies before he starts receiving benefits from his pension, then a properly drafted QPSA clause will provide the alternate payee with a lifetime stream of actuarially adjusted pension payments. ${ }^{496}$ If a shared-interest QDRO does not include pre-retirement and post-retirement survivor protection for the alternate payee, then her payments will cease when the participant dies. ${ }^{497}$ If she wants a lifetime stream of payments under the sharedinterest approach, then the QDRO must include pre-retirement and post-retirement survivor-annuity protection. If the participant is retired and receiving pension payments at the time of divorce, then a

491. Id. § 6.03.

492. DiETRICH, supra note 421, § 10.02[2]; SHULMAN, supra note 16, § 6.03 .

493. SHULMAN, supra note $16, \S 6.03$.

494. Id.

495. Id. § 6.03[B].

496. Id.

497. Id. § 6.03 . 
separate-interest approach is the only option available because "[i]t is too late [for the plan] to actuarially adjust the alternate payee's benefits to her own life expectancy." 498

The model orders of many plans are written using the sharedinterest approach, which vests the participant with control over the timing and receipt of benefits for the participant and the alternate payee. ${ }^{499}$ Plans do not do this to disadvantage the alternate payee; plans do this because the shared-interest approach is easier, less costly, and requires fewer actuarial calculations. ${ }^{500}$ This is yet another example of how blithely using the model order can be quite costly to the alternate payee.

\section{Assigning Vested Benefits Rather than Accrued Benefits}

The language of most model QDROs divides the participant's "vested benefit rather than his accrued benefit." 501 The vested-benefit number is smaller than the accrued-benefit number. ${ }^{502}$ Benefits that have accrued but have yet to vest can be marital or community property. Thus, it is essential to divide the accrued number rather than the vested number. ${ }^{503}$

\section{Investment Gains and Losses in Defined-Contribution Plans}

A plan's model order typically states that the balance of an alternate payee's share of the participant's account will include investment gains, losses, dividends, and interest from the date of division specified in the QDRO until the date that the alternate payee receives her share. ${ }^{504}$ An alternate payee may not want to assume the risk that her share of the participant's account will decrease in value; therefore, she may want to eliminate the language adjusting her account for gains, losses, dividends, and interest. Of course, this means that she will not get the benefit of increases either. If she wants to take a chance that the account will make market gains, then she also must the risk that it will suffer market losses.

498. Id. § 6.03[D].

499. CARRAD, supra note 9, at 107.

500. Id. at 108 .

501. Id. at 109.

502. Id.

503. Id.

504. Id. at 109-10. 


\section{Division of Year-End Contributions}

A considerable number of employers make yearly contributions to their employees' retirement accounts. ${ }^{505}$ If the participant and alternate payee divorce in the middle of the plan year, then an adjustment will need to be made to properly divide this end-of-year employer contribution. ${ }^{506}$ For example: Acme's pension plan's fiscal year ends on September $30 .^{507}$ On that day, the company contributed $\$ 12,000$ to Husband's account based on his service during the fiscal year. ${ }^{508}$ Husband and Wife get divorced on May 31, which is eight months into the fiscal year. ${ }^{509}$ Because Wife was married to Husband for $8 / 12$ or $2 / 3$ of the fiscal year for which Husband will receive an end-of-year contribution, she should receive $2 / 3$ of the $\$ 12,000$ or $\$ 8,000$. $^{510}$

The employer's model QDRO will not include adjustments for year-end contributions. The only way that the alternate payee will get her share of this marital asset is to include a provision in the QDRO that states she is entitled to a specific portion of employer contributions made to the participant's account for any time that is attributable to the participant's employment. This is true whether those contributions are made before or after the cutoff date for property division under state law. ${ }^{511}$

\section{Allocation of Forfeitures}

ERISA allows an employer to delay the vesting of contributions made by the employer to an employee's retirement plan for up to seven years. ${ }^{512}$ The purpose of the delay is to incentivize employees to keep working for the employer. ${ }^{513}$ Once the employee becomes vested in a benefit, it is non-forfeitable. ${ }^{514}$ Conversely, as long as the benefit is accrued, but not vested, it can be lost if the employee quits

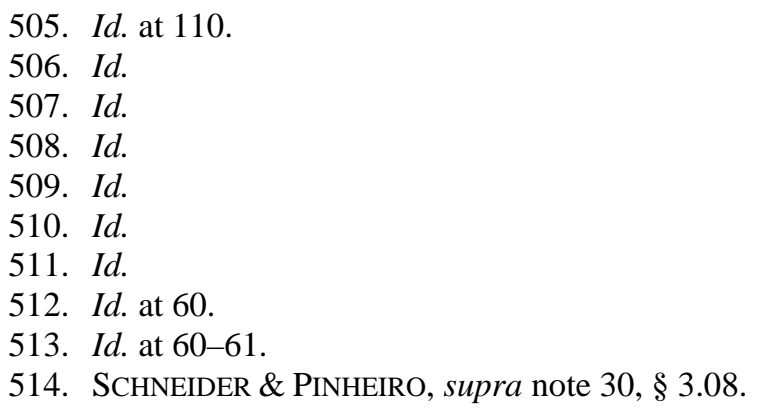


or is fired. ${ }^{515}$ ERISA allows two vesting schedules, one for definedbenefit plans ${ }^{516}$ and one for defined-contribution plans. ${ }^{517}$ These schedules set a floor, not a ceiling, on when vesting must occur; plans may offer vesting on a more accelerated basis if the employer chooses to do so. ${ }^{518}$ The schedules apply only to employer contributions; an employee is always entitled to the entirety of his or her contributions to his retirement plan. ${ }^{519}$ Likewise, if an employee dies or the plan terminates, then the employee becomes $100 \%$ vested in the employee's and the employer's contributions. ${ }^{520}$

Assume that Grady has $\$ 400$ in a defined-contribution plan after he completes his fourth year of service. ${ }^{521}$ Following the ERISA vesting schedule for defined-contribution plans, Grady will be $60 \%$ vested in the employer's contributions to his plan. ${ }^{522}$ If Grady quits or is fired at this point, then he would be entitled to $\$ 240$, which is $60 \%$ of the employer's contributions, leaving $\$ 160$ in his plan. ${ }^{523}$ Something must be done with this money, but it cannot simply be returned to the employer's coffers as profit ${ }^{524}$ because the employer received a tax deduction for the $\$ 400$ contribution it made to Grady's plan. ERISA does not allow the employer to keep this money. ${ }^{525}$ Instead, the $\$ 160$ will be spread among the other plan participants on a pro rata basis, typically based on their salaries during the year. ${ }^{526}$

515. Id. § 3.08[B].

516. 29 U.S.C. § 1053(a)(2)(A)(i)-(iii) (2006 \& Supp. IV 2011). The vesting schedule is as follows: after three years of service the employee's non-forfeitable percentage of the employer's contributions is $20 \%$; after four years, $40 \%$; after five years, $60 \%$; after six years, $80 \%$; after seven years or more, $100 \%$. $\S$ 1053(a)(2)(A)(iii).

517. 29 U.S.C. § 1053(a)(2)(B)(i)-(iii). The vesting schedule is as follows: after two years of service the employee's non-forfeitable percentage of the employer's contributions is $20 \%$; after three years, $40 \%$; after four years, $60 \%$; after five years, 80\%; after six years or more, $100 \%$. § 1053(a)(2)(B)(iii).

518. CARRAD, supra note 9, at 60-61.

519. 29 U.S.C. § 1053(a)(1).

520. 29 U.S.C. $\S 1053(\mathrm{a})(3)(\mathrm{A})$.

521. CARRAD, supra note 9 , at 62.

522. Id.

523. Id.

524. Id. at 63. It can, however, be used to pay for future benefits or plan expenses. $I d$.

525. Id.

526. Id. 
For example: Assume the plan in which Grady participates has two other participants: Fred and Lamont. ${ }^{527}$ When Grady's employment ends and $\$ 160$ of his $\$ 400$ is forfeited, Fred earns $\$ 25,000$ annually and Lamont earns $\$ 75,000 .{ }^{528}$ On the date that the forfeitures are allocated, Fred will receive 25\% of the forfeited $\$ 160$ (\$40), and Lamont will receive $75 \%$ of the forfeited $\$ 160$ (\$120). ${ }^{529}$ Forfeitures are typically allocated once per fiscal year based on events during the preceding two years. ${ }^{530}$ This is because ERISA requires plans to wait at least one year after the employee leaves to see if he returns. If the employee does, then he service will be considered uninterrupted, and he will not lose the non-vested portion of his plan account that he would have lost had the employee not returned. $^{531}$ If the employee does not return within a year after leaving, then the plan is authorized to allocate the non-vested portion of his account to the remaining participants in the plan. ${ }^{532}$ The earliest this allocation can take place is the end of the plan's next fiscal year following the one-year anniversary of the former employee's cessation of employment. This can result in a two- to three-year delay in the allocation of forfeitures to the remaining participants. ${ }^{533}$

A properly drafted QDRO should treat the allocation of forfeitures the same way that it treats year-end contributions, e.g., if Husband and Wife divorce during the middle of the plan's fiscal year, then the forfeitures allocated to Husband's account one or two years later should be divided into marital and nonmarital portions. ${ }^{534}$ The QDRO should state that an alternate payee will receive one-half of all forfeitures allocated to the participant's plan account that were attributable to his service during the period ending on the date of divorce. This is the case whether the forfeitures are allocated to his plan before or after the cutoff date for the division of property under

527. Id.

528. Id.

529. Id.

530. Id.

531. Id.

532. Id.

533. Id.

534. Id. 
state law. ${ }^{535}$ This is yet another consideration that will not be addressed in a plan's model QDRO.

\section{Proper Handling of Loans in Defined-Contribution Plans}

A plan administrator must be instructed in the QDRO on how to handle outstanding loans against the participant's account balance in a defined-contribution plan. ERISA authorizes two exceptions to its spendthrift clause: a QDRO and a revocable assignment of up to 10\% of future benefits. ${ }^{536}$ Participants occasionally take out loans against their plans, and this must be considered when dividing a plan with an outstanding loan against it. From a lay person's point of view, a loan is a liability. "From the plan's point of view[, however,] a loan is an asset." ${ }^{537}$ For example: A participant's account balance consists of $\$ 100,000$ in mutual funds and a $\$ 20,000$ loan owed by the participant. $^{538}$ If an alternate payee is awarded one-half of the account balance excluding the loan, then she will get \$50,000 (50\% of $\$ 100,000) .{ }^{539}$ On the other hand, if she is awarded one-half of the account including the loan, then she will get $\$ 60,000$ (50\% of $\$ 120,000) .{ }^{540}$ The loan is an account receivable to the plan but an account payable to the participant. The participant is repaying himself when he repays the loan. A QDRO that does not add loan amounts to the amount to be divided could significantly shortchange the alternate payee. It is the drafting lawyer's responsibility to determine if there is a loan balance and then to make sure that the alternate payee receives her share of that account receivable.

\section{The PBGC and Defined-Benefit Plans}

ERISA established the PBGC to provide the pension-termination insurance that did not exist when the Studebaker plant closed on December 9, 1963, and terminated its defined-benefit plan. ${ }^{541}$ The PBGC “insures the pension benefits of a corporation's employees if

535. Id. at 64 .

536. 29 U.S.C. § 1056(d)(2) (2006).

537. CARRAD, supra note 9 , at 131.

538. Id.

539. Id.

540. Id.

541. 29 U.S.C. § 1302; Dean, supra note 9, at 648; U.S. Gov’T ACCOUNTABILITY OFFICE, supra note 135. 
[the] company sponsoring an underfunded defined benefit pension plan becomes insolvent." 542 The PBGC "becomes trustee of the plan and its assets, and [it] is then responsible for investing those assets and paying benefits to the plan's participants." ${ }^{443}$ In 2010, the PBGC "paid nearly $\$ 5.6$ billion for approximately 801,000 retirees in 4,200 failed plans."544

The PBGC will not pay plan benefits above certain limits, and in almost all cases, PBGC payments will be lower than plan payments. In 2011, the maximum monthly payment that the PBGC would make

542. U.S. Gov’T ACCOUNTABILITY OfFICE, supra note 135.

543. Id.

544. Pension Benefit Guar. Corp., 2010 Annual Report 2 (2010), available at http://www.pbgc.gov/Documents/2010_annual_report.pdf. The PBCG, however, has its own fiscal problems; in the first half of fiscal year 2009, the agency had a deficit in excess of $\$ 33$ billion - an increase of more than $\$ 22$ billion over the prior fiscal year's $\$ 11$ billion deficit. Press Release, Pension Benefit Guar. Corp., PBGC Deficit Climbs to 33.5B at Mid-Year, Snowbarger to Tell Senate Panel (May 20, 2009), available at http://www.pbgc.gov/news/press/releases/pr09-30.html.

"The increase in the PBGC's deficit is driven primarily by a drop in interest rates and by plan terminations, not by investment losses.” . . . "The PBGC has sufficient funds to meet its benefit obligations for many years because benefits are paid monthly over the lifetimes of beneficiaries, not as lump sums. Nevertheless, over the long term, the deficit must be addressed.”

The \$22.5 billion deficit increase was due primarily to about \$11 billion in completed and probable pension plan terminations; about $\$ 7$ billion resulted from a decrease in the interest factor used to value liabilities; about \$3 billion in investment losses; and about \$2 billion in actuarial charges.

[On] April 30, [2009,] the PBGC's investment portfolio consisted of $30 \%$ equities, $68 \%$ bonds, and less than $2 \%$ alternatives, such as private equity and real estate. All the agency's alternative investments [were] inherited from failed pension plans....

According to PBGC estimates, auto sector pensions are underfunded by about $\$ 77$ billion, of which $\$ 42$ billion would be guaranteed in the event of plan termination. [The PBGC] also faces increased exposure from weak companies across all sectors of the economy, including retail, financial services and health care. . . .

The agency receives no funds from general tax revenues. Operations are financed largely by insurance premiums paid by companies that sponsor pension plans and by investment returns.

Id. 
for a single-life annuity at the age of 65 was $\$ 4,500 .^{545}$ The maximum monthly payment for a joint-and-survivor annuity was $\$ 4,050$. $^{546}$ The PBGC will not pay a participant more than what he would have received from his plan. If the PBGC has to pay a participant less than what he would have received from his plan and a QDRO lacks a provision that specifies how an alternate payee is to share in the PBGC payments, then the alternate payee could receive nothing from the PBGC. A properly drafted QDRO should include a provision stating that in the event the PBGC takes over a definedbenefit plan, the percentage difference in the alternate payee's PBGC payment and her original payment will be equal to the percentage difference in the participant's PBGC payment and his original payment. $^{547}$

It is nearly impossible to find a plan's model QDRO with a provision that addresses what to do in the event that the PBGC takes over the plan. ${ }^{548}$ This is because when the PBGC takes over a plan, the plan's administrator is replaced, so he has no continuing interest in what happens after that. ${ }^{549}$ The parties' attorneys must provide for each party in the event that a PBGC takeover occurs. ${ }^{550}$

\section{VERIFY THAT THE QDRO Is APPROVED BY THE PlAN ADMINISTRATOR}

A nationally known, well-regarded QDRO expert who formerly served as a plan administrator observed that between 15\% and $20 \%$ of the time when an order did not qualify as a QDRO, the drafter simply gave up. ${ }^{551}$ It is the drafter's responsibility-not the plan administrator's - to make the changes necessary to get the order qualified and effectuated. ${ }^{552}$ Failure to do so will result in the alternate payee permanently losing her rights to her share of the

545. Pension Benefit Guar. Corp., Maximum Monthly Guarantee TABLES, http://www.pbgc.gov/wr/benefits/guaranteed-benefits/maximumguarantee.html\#2011 (last visited Jan. 12, 2012).

546. Id.

547. CARRAD, supra note 9, at 131; SHULMAN, supra note 16, § 4.09[P].

548. CARRAD, supra note 9 , at 102.

549. Id.

550. Id.

551. Id. at 9.

552. SHULMAN, supra note 16, § 16.02[H]. 
participant's benefits. ${ }^{553}$ This constitutes professional misconduct and malpractice. ${ }^{554}$ Also, it is not enough to just send the plan administrator an order for a QDRO determination. ${ }^{555}$ The drafter has to be persistent and follow up with the plan administrator until the order is qualified. ${ }^{556}$ Plan administrators sometimes lose or mislay orders waiting to be qualified. ${ }^{557}$ If this happens and a QDRO is never entered, then the alternate payee's rights will be lost, and it will be the lawyer's fault-not the plan's. ${ }^{558}$ Once the order is sent to the plan administrator, the attorney should follow up in writing every fourteen days until the order is qualified. ${ }^{559}$ If it does not get qualified the first, second, or even the third time, then the attorney must work diligently to make the changes necessary to have it qualified. ${ }^{560}$ Once the order is qualified, the attorney should obtain a written confirmation from the plan administrator verifying that fact and send that writing to the client. ${ }^{561}$ Remember: the lawyer's duty is not fulfilled until the QDRO is accepted and put into effect. ${ }^{562}$

The foregoing are not all of the areas of concern that a domesticrelations practitioner must consider in drafting or reviewing a QDRO. The subject is complex enough that one article could not possibly cover every conceivable pitfall or trap for the unwary. The areas addressed in this Article, however, are ones that arise quite often.

\section{CONCLUSION}

As long as people get married in America, people will get divorced. On August 23, 1984, the job of the domestic-relations practitioner became more complex with the introduction of the QDRO. All domestic-relations practitioners must learn the ins and outs of QDROs - there is no other choice. The learning curve can be steep, but it is not insurmountable. Excellent, user-friendly resources

553. CARRAD, supra note 9 , at 9 .

554. Id.

555. Id.

556. Id. at 154 .

557. Id. (citing Fortmann v. Avon Prods., Inc., No. 97 C 5286, 1999 WL 160258, at *1-9 (N.D. Ill. Mar. 9, 1999)).

558. Id.

559. Id.

560. Id. at 155 .

561. Id.

562. Id. at 154. 
are available, ${ }^{563}$ and it is my hope that this Article becomes one of those resources. Happy QDRO drafting.

563. CARRAD, supra note 9; SHULMAN, supra note 16; SNYDER, supra note 27; U.S. DEPT. OF LABOR, The Division of Retirement Benefits Through Qualified Domestic Relations Orders, DOL.GOV, http://www.dol.gov/ebsa/publications/qdros.html (last visited Jan. 12, 2012). 
